\title{
Początki krzyżackich zamków na ziemi chelmińskiej. Pierwsze warownie i obiekty murowane
}

\section{The origins of the Teutonic Order's castles in Chelmno Land. First strongholds and mortared structures}

Zarys treści. W artykule zaprezentowano rozwój krzyżackiego budownictwa warownego w ciągu pierwszych dziesięcioleci tworzenia przez braci-rycerzy zrębów państwa w Prusach. Wznoszone najpierw założenia drewniano-ziemne, zapewniające kontrolę nowo zajmowanych ziem oraz osadnictwa, przeanalizowano w kontekście tzw. zamków typu przejściowego. W dalszej kolejności scharakteryzowano pierwsze fazy murowane zamków krzyżackich, powstałe w wyniku rozbudowy starszych założeń drewniano-ziemnych; obiekty te stanowiły centra nowych komturstw. Podjęto także próbę ukazania tych pierwszych skromnych założeń w kontekście innych środkowoeuropejskich siedzib krzyżackich.

Stowa kluczowe: zamki, Krzyżacy, ziemia chełmińska, architektura średniowieczna.

Mimo niemal dwustuletniej tradycji badań stan wiedzy na temat początków krzyżackiego budownictwa warownego w Prusach jest nadal dość ograniczony (Arszyński 1995, s. 51-74). Jednak już w XIX wieku badacze dostrzegali, że w XIII stuleciu Krzyżacy, obok murowanych obiektów, wznosili także drewniano-ziemne. Wymienić tu można choćby Maxa Toeppena (1880, s. 2-6), który wskazywał ponadto, że murowane zamki mogły poprzedzać obiekty z nietrwałych materiałów. Symptomatyczne dla epoki jest tu poparcie przez niego argumentacji stwierdzeniem, że „ein Dorf, ja eine Stadt in polnischen Geschmack kann spurlos vom Erdboden verschwinden, aber ein Ordenshaus nicht" (Toeppen 1880, s. 3). Fakt obecności grodów został jednak wprzęgnięty w pełni w machinę propagandową podczas drugiej wojny światowej, kiedy to prowadzący badania na zamku 
w Grudziądzu Hans Jacobi sugerował, że Słowianie przejęli formy budownictwa grodowego od Germanów (Jacobi 1996, s. 25). Po wojnie zapanowało natomiast powszechne przekonanie, że Krzyżacy standardowo wznosili swoje zamki w miejscu starszych, słowiańskich bądź pruskich grodów (m.in. Guerquin 1984, s. 47). Pojawiały się nawet głosy, że wieloczłonowe układy zamków krzyżackich należy wywodzić od topografii lokalnych grodów (Byczko 1962). Współczesne badania pozwoliły te poglądy zweryfikować i ukazać znacznie bardziej złożoną sytuację. Co prawda w przypadku zamków nieregularnych wydaje się, iż często wznoszono je w miejscu starszych warowni drewniano-ziemnych, przy czym należy rozróżnić obecność wczesnośredniowiecznego grodu od krzyżackiej warowni drewniano-ziemnej, ale już późniejsze zamki kasztelowe murowano najchętniej na tzw. surowym korzeniu, choć są wyjątki, o czym świadczy na przykład zamek gdański (Wasik 2016, s. 31-32, 319). W niniejszym artykule skupimy się na tych wczesnych krzyżackich warowniach drewniano-ziemnych oraz na pierwszych inwestycjach murowanych, stanowiących kontynuację niektórych z tych obiektów, prowadzonych przed okresem rozwoju budownictwa kasztelowego.

Pierwsze warownie krzyżackie powstały na lewym (kujawskim) brzegu Wisły, gdyż ziemia chełmińska była opanowana przez Prusów. Należy tu wymienić wzniesiony dla Krzyżaków przez Konrada Mazowieckiego Vogelsang oraz wybudowany lub odbudowany przez nich w 1230 roku gród w Nieszawie. Zdobycie w 1231 roku przyczółka na prawym brzegu Wisły i budowa tam strażnicy (Stary Toruń) zabezpieczającej przeprawę ze strażnic kujawskich, umożliwiło Zakonowi dalszy podbój (Poliński 2003, s. 171-172; Dygo 2008, s. 64-65). W miarę zajmowania kolejnych obszarów Krzyżacy wznosili nowe warownie; lokowano je wzdłuż wodnych szlaków komunikacyjnych i na terenie przedkrzyżackich skupisk osadniczych (Poliński 2007a, s. 163). Po wkroczeniu na ziemię chełmińską Krzyżacy wznieśli w latach 30. XIII wieku kilka obiektów: wspomniany Stary Toruń (1231 rok), Starogród (Stare Chełmno, 1232 rok), Radzyń Chełmiński (1234 rok), Grudziądz (1234 rok), translokowany Toruń (1236 rok), Bierzgłowo (1236 rok), Pokrzywno (lata 30. XIII wieku) oraz Kowalewo Pomorskie; w Pomezanii był to Kwidzyń (1233 rok). W kolejnych dziesięcioleciach powstały: Słup (1256 rok), Potterberg (lata 1253-1257), Wieldządz (2. połowa XIII wieku) (Torbus 1998, s. 361, 400, 427, 637; Poliński 2003, s. 182; 2005, s. 188; 2007a, s. 160; 2007b, s. 48-49, 52; Dygo 2008, s. 65). Przykłady te bynajmniej nie wyczerpują listy.

W literaturze do niedawna traktowano wymienione warownie jako prostą kontynuację budownictwa grodowego (Arszyński 1995, s. 123; 2000, s. 20); jest to jednak uproszczenie. Wiek XIII był okresem przejściowym; miały wówczas miejsce duże zmiany społeczno-gospodarcze, wynikające z rozwoju ustroju feudalnego (Kajzer 1993, s. 69-70, 92), z którym to związany był rozwój budownictwa zamkowego. Tradycyjne grody natomiast łączyły się z poprzednimi ustrojami. Nieprzypadkowo więc rok 1230 został uznany przez Bohdana Guerquina za cezurę 
rozpoczynającą czas wznoszenia zamków w Polsce (Guerquin 1984, s. 15, 44). Co prawda data ta jest symboliczna, związana z przebudową legnickiego grodu w zamek, a okres przeżywania się systemu grodowego na różnych terenach ziem polskich kształtował się nieco odmiennie, jednak trafnie odpowiada przemianom jakie nastąpiły na ziemi chełmińskiej. Był to bowiem czas przybycia pierwszych rycerzy krzyżackich i początku podboju. Wraz z ich pojawieniem się, na zajmowanych terenach rozpoczęły się przemiany społeczne, gospodarcze i prawne, kończące okres prawa książęcego na ziemi chełmińskiej. Przejawiało się to między innymi lokacją pierwszych miast (Torunia i Chełmna) oraz nadaniem im prawa chełmińskiego w 1233 roku; były one jednymi z fundamentów, w oparciu o które Krzyżacy budowali swoje państwo (Czaja 2013, s. 81-84). Ważnymi elementami różniącymi zamki od grodów były formacje społeczno-gospodarcze, w których kontekście te warowne siedziby funkcjonowały. Należy dodać, że materiał budowlany w kwestii definicji ,zamku” nie jest decydujący i jednoznaczny (Kajzer 1993, s. 13-14), a stosowanie wałów i drewnianej zabudowy nie determinuje przypisania obiektu automatycznie do budownictwa grodowego. Zazwyczaj nawet murowane zamki miały mniej lub więcej obiektów drewnianych (Marciniak-Kajzer 2002, s. 491-496), a w nowożytności na kresach Rzeczypospolitej wznoszono jeszcze warownie całkowicie drewniano-ziemne, otoczone wałami o konstrukcjach izbicowych (Adamczyk 2004, s. 60-63). Przełomowe w tym zakresie są wyniki badań archeologów czeskich sprzed około czterech dekad, ustalili oni, że dla 2. ćwierci i połowy XIII wieku charakterystyczne były obiekty określone mianem zamków typu przejściowego (Durdík 1994, s. 9-10; Durdík, Bolina 2001, s. 76-77) ${ }^{1}$. Warownie tego rodzaju stwierdzono także na Śląsku, gdzie datowane są na 3. ćwierć XIII wieku (Boguszewicz 1998, s. 103-105). W obu przypadkach były to obiekty związane z władzą centralną - królewską w pierwszym przypadku i książęcą $\mathrm{w}$ drugim. Powstawanie zamków typu przejściowego powiązane było z rozpadem systemu prawa książęcego, postępującą feudalizacją stosunków społecznych oraz kolonizacją. Stanowiły nowe centra ułatwiające kontrolę osadnictwa i zagospodarowywanych terenów.

Do lepiej poznanych czeskich zamków typu przejściowego należą między innymi: Hlavačov, Angerbach u Kožlan (ryc. 1) i Týnec nad Sázavou (Durdík 2000, s. 50-51, 161-162, 567-568). Wznoszono je najczęściej na tzw. surowym korzeniu, choć znane są też warownie powstałe na miejscu wczesnośredniowiecznego grodu, jak na przykład Tachov. Cechowało je proste budownictwo, przede wszystkim z nietrwałych materiałów. Obiekty te nie uchodzą jednak za zwykłą kontynuację budownictwa grodowego, między innymi dlatego, że wały zamków typu przejściowego nie posiadały charakterystycznych dla poprzedniego okresu wewnętrznych konstrukcji drewnianych. Wznoszono je z ziemi, rzadko

${ }^{1}$ Odnośnie interesującego nas obszaru tematykę tą poruszał Dariusz Poliński (m.in. 2005; 2007a; 2007b). 


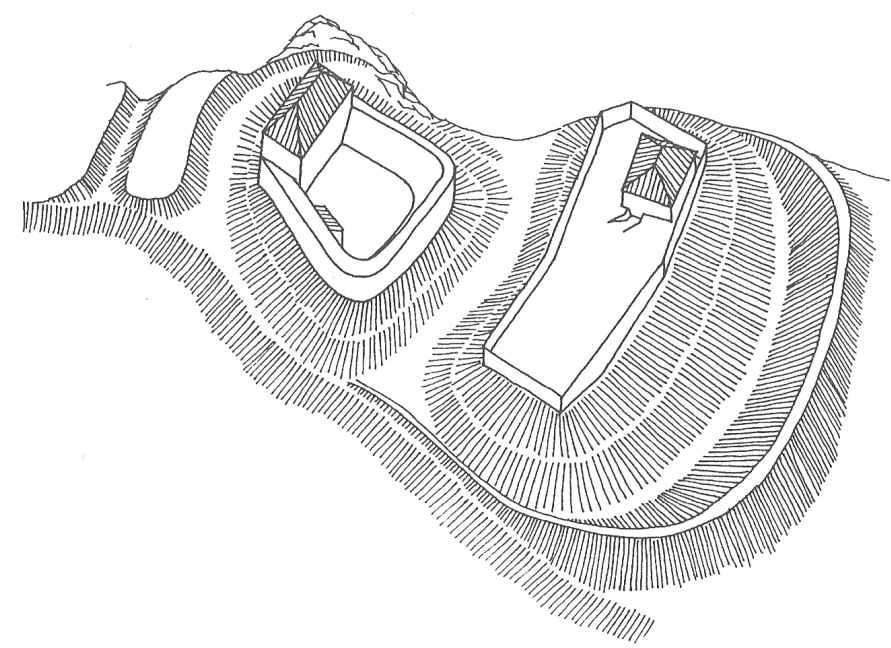

Ryc. 1. Angerbach u Kožlan, Czechy. Przykład zamku typu przejściowego (wg Durdík 2000)

Fig. 1. Angerbach u Kožlan, Bohemia. An example of a castle of transition type (after Durdík 2000)

pozostawiając odsłonięte stoki, które wzmacniano najczęściej kamiennymi płaszczami bądź drewnianymi ścianami. Mogły to być założenia dwuczłonowe, jak Angerbach, gdzie wewnętrzna zabudowa opierała się o wały i była z nimi związana. Tworzyły ją pojedyncze budynki (dwory) wznoszone z drewna lub w technice szkieletowej. W Angerbach znajdował się ponadto duży, zagłębiony w ziemi budynek z kamieni łączonych gliną, określany ziemianką (Durdík 1994, s. 9-10; 2000, s. 50-51, 548; Durdík, Bolina 2001, s. 76-80). Ogólnie podobne cechy miały założenia Śląskie, na przykład Pieszyce (Boguszewicz 1998, s. 104). Biorąc pod uwagę także wspomniane uwarunkowania społeczno-gospodarcze były to de facto zamki budowane z nietrwałych materiałów.

Podobne jak zaprezentowane wyżej i charakterystyczne dla Europy Środkowej przemiany społeczno-gospodarcze zachodziły także w XIII wieku na ziemi chełmińskiej i w Prusach. Przy czym na interesującym nas obszarze, w związku z przybyciem nowej warstwy rządzącej z zewnątrz, jej zakonnym charakterem i warunkami wojennymi, przekształcenia te miały bardziej gwałtowny i nieco odmienny charakter. Transformację tę ułatwiał z pewnością stan, w jakim znajdowały się starsze lokalne fortyfikacje i ośrodki władzy. Jak wynika z dokumentu z Lonyz, kiedy Krzyżacy zajęli ziemię chełmińską, znaczna część grodów była opuszczona i zapewne w większym lub mniejszym stopniu wymagały one odbudowy po zniszczeniach wojennych (Powierski 1983, s. 17-18; Poliński 2003, s. 125, 172; 2007a, s. 158). Nowi właściciele musieli więc adaptować stare i wznosić nowe warownie, aby ugruntować swoje zdobycze terytorialne i wspierać dalsze działania wojenne (Arszyński 1995, s. 117-118, 123; 2000, s. 29; Poliński 2007b, s. 41). 
Scharakteryzowanie wyglądu XIII-wiecznych krzyżackich warowni drewniano-ziemnych nie jest łatwe, gdyż żaden z tych obiektów nie został dostatecznie przebadany, a budowa w tych miejscach murowanych zamków niekiedy w dużym stopniu zniszczyła ich ślady. Niemniej prace wykopaliskowe prowadzone w obrębie różnych warowni oraz skąpe przesłanki w źródłach pisanych pozwalają naszkicować ich ogólne cechy. Poznanie pewnych właściwości tych wczesnych obiektów umożliwia także kontynuacja tej tradycji po XIII wieku w Prusach².

W przeciwieństwie do przykładów czeskich, XIII-wieczne krzyżackie zamki typu przejściowego wznoszone były najczęściej w oparciu o stare grody, na przykład obiekty w Grudziądzu, Kałdusie (pierwotne Chełmno), Pokrzywnie, Słupie, Wieldządzu, translokowanym Kwidzynie (Boguwolski 1994, s. 191-193; Boguwolski, Grupa 1994, s. 143; Boguwolski, Kola 1994, s. 165; Kola 1994, s. 90; Herrmann 2007, s. 591; Chudziak, Kurzyńska 2012, s. 173-190). Powstawały też obiekty na tzw. surowym korzeniu, na przykład pierwsza warownia na Żuławie Kwidzyńskiej i Starogród (Dusburg 2004, s. 49-50; Poliński 2007b, s. 52; Wasik 2016, s. 25-32) oraz młodsze, datowane na XIV wiek - Słoszewy i Gruta (Kola 1991, s. 169, 213).

Krzyżackie warownie drewniano-ziemne wznoszone na zrębach wczesnośredniowiecznych grodów powtarzały w naturalny sposób obrys tych ostatnich; taką sytuację odnotowano w Słupie (ryc. 2) i Wieldządzu (ryc. 3). Obiekty te były zatem w rzucie zbliżone do owalu, natomiast w Toruniu wczesnośredniowieczny gród miał mieć plan podkowiasty, przy czym obecność wału potwierdzono de facto tylko od wschodu i północnego wschodu ${ }^{3}$. Warownie lokowane na tzw. surowym korzeniu miały także czworoboczne rzuty, na przykład Gruta czy Słoszewy ${ }^{4}$ (ryc. 4). Warto dodać, że niektóre warownie, jak Słup i Wieldządz, posiadały przygródki (Chudziakowa, Kola 1974, s. 8-9; Kola 1991, s. 167, 176, 209, 213; Boguwolski, Kola 1994, s. 161; Boguwolski, Kurzyńska 2001, s. 143-145, 158).

Niestety, stan badań nie pozwala na szczegółowe scharakteryzowanie konstrukcji wałów interesujących nas warowni. Rozpoznanie to utrudnia też fakt, że na niektórych XIII-wiecznych obiektach wzniesiono później zamki murowane. Dobrze ilustruje to przykład Grudziądza, gdzie w świetle dotychczasowej wiedzy brakuje śladów fortyfikacji krzyżackiego obiektu drewniano-ziemnego (podobnie jak grodu). Być może wynika to $\mathrm{z}$ faktu, że miały one postać prostego

2 Tradycja budowania warowni drewniano-ziemnych utrzymała się długo, między innymi na wschodnich, objętych walkami obszarach aż do początku XV wieku.

${ }^{3}$ W wykopie 6/09, wytyczonym podczas badań prowadzonych przez Adama Chęcia po zachodniej stronie domu konwentu, nie zarejestrowano reliktów wału (Chęć 2009). Można to tłumaczyć jego brakiem $\mathrm{z}$ tej strony, jak również zniszczeniem ewentualnych pozostałości podczas budowy murowanego zamku.

${ }^{4}$ Jak wynika z wykonanych pomiarem laserowym (ISOK) map cieniowych dostępnych na portalu geoportal.gov.pl, założenia w Grucie i Słoszewach miały znacznie bardziej regularny obrys niż ukazują to znane $\mathrm{z}$ literatury rzuty. 


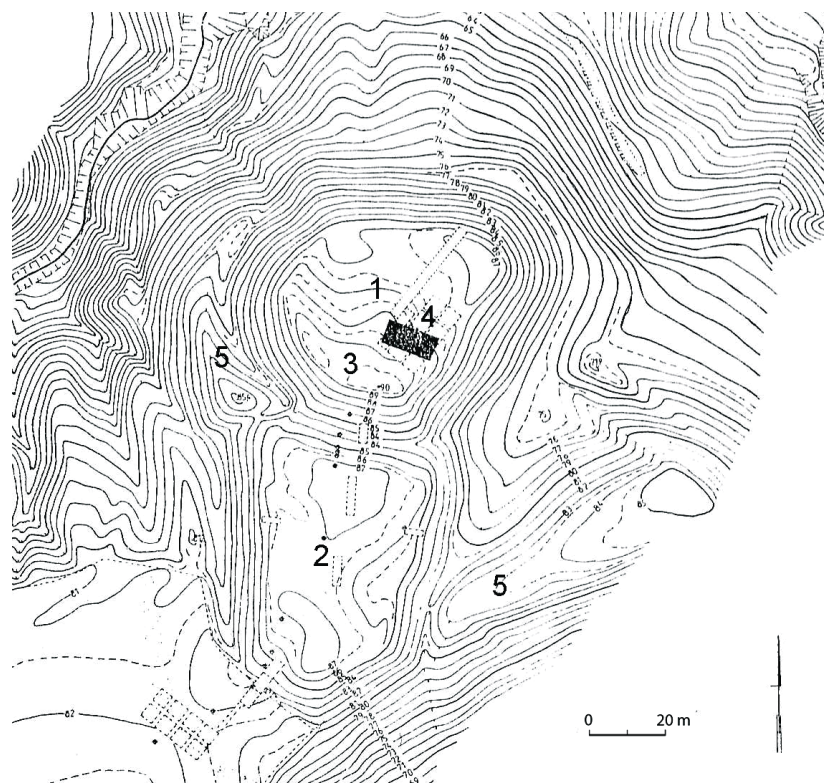

Ryc. 2. Słup, pow. Grudziądz. Rzut warowni: 1 - człon główny, 2 - przygródek, 3 - wał czołowy, 4 - budynek, 5 - wały zewnętrzne (wg Kola 1991)

Fig. 2. Słup, Grudziądz district. Plan of stronghold: 1 - main segment, 2 - outworks, 3 - front rampart, 4 - building, 5 - outer ramparts (after Kola 1991)

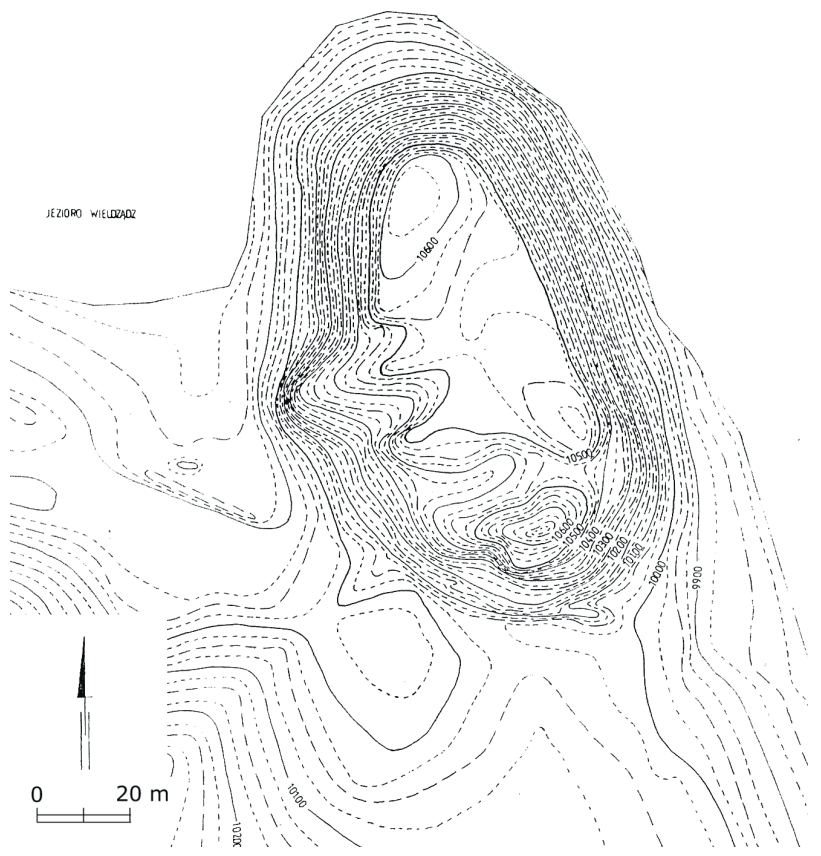

Ryc. 3. Wieldządz, pow. Wąbrzeźno. Rzut warowni drewniano-ziemnej (wg Kola 1991)

Fig. 3. Wieldządz, Wąbrzeźno district. Plan of wooden and earthen stronghold (after Kola 1991) 

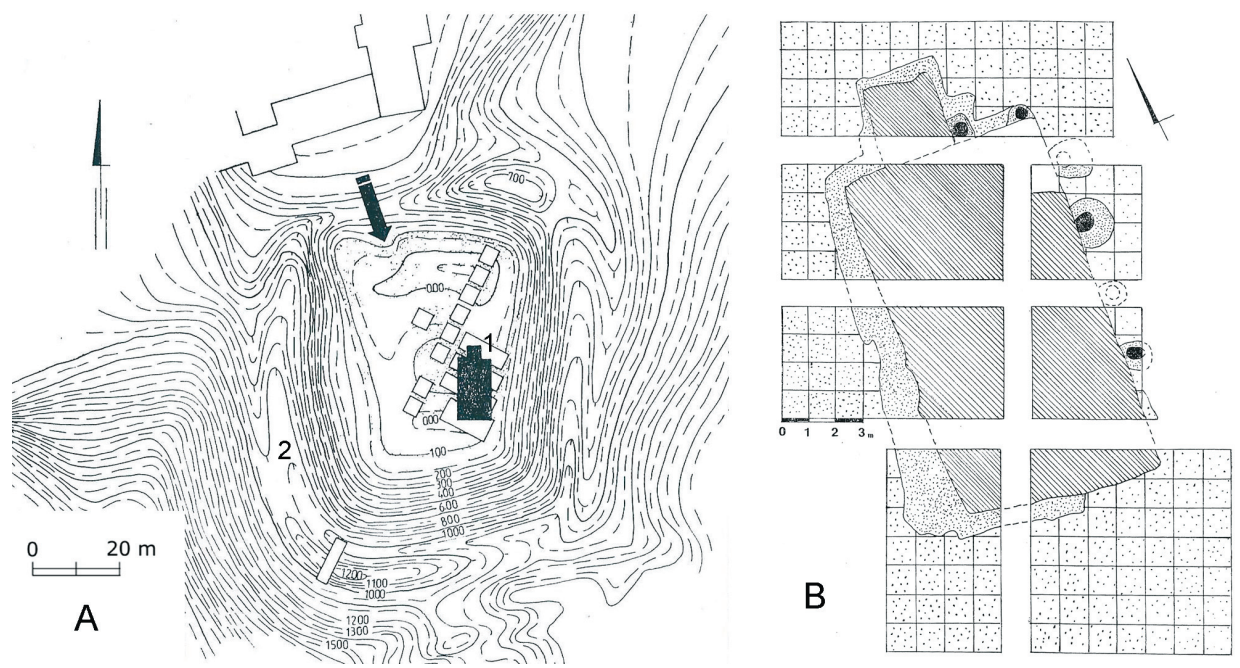

Ryc. 4. Słoszewy, pow. Brodnica. Rzut warowni (A: 1 - budynek, 2 - wał zewnętrzny) i budynku (B) (wg Kola 1991)

Fig. 4. Słoszewy, Brodnica district. Plan of stronghold (A: 1 - building, 2 - outer rampart) and building (B) (after Kola 1991)

i niedużego wału ziemnego oraz palisad, które całkowicie zostały usunięte podczas późniejszej budowy. W Pokrzywnie natomiast relikty drewniano-ziemnego wału odkryto w północnej części zamku wysokiego, przy czym brakuje jednoznacznej interpretacji, czy należy go łączyć z wczesnośredniowiecznym grodem, czy z czasami krzyżackimi (Boguwolski 1975, s. 192; Boguwolski, Kurzyńska 2001, s. 129). W Toruniu obecność wału w obrębie wschodniego parchamu stwierdzono już podczas badań na przełomie lat 50. i 60. XX wieku (Chudziakowa, Kola 1974, s. 26-28). Potwierdza to analiza wyników prac wykopaliskowych prowadzonych w ostatnich latach (Wasik 2016, s. 85-93). Pierwotnie wał rekonstruowany był jako drewniano-ziemny, jednak podczas nowszych badań nie zarejestrowano śladów konstrukcji drewnianych ${ }^{5}$ (ryc. 5). Podobne obserwacje można poczynić poza ziemią chełmińską, na przykład pod krzyżackim zamkiem w Kwidzynie, gdzie podczas badań w latach 30. XX wieku również stwierdzono pozostałości drewniano-ziemnych wałów pruskiego grodu zaadaptowanego przez Krzyżaków. W ich obrębie znajdowały się także ślady wzmacniania bramy (Heym 1933, s. 13-14, 21-25).

W przypadku adaptowania wczesnośredniowiecznych grodów wykorzystywano i wzmacniano ich wały. W Wieldządzu wzniesiono wał osłonowy i fosę od

${ }^{5}$ Niestety, materiały z badań prowadzonych przez Adama Chęcia w latach 2008-2011 nie doczekały się opracowania. Trudno więc ustalić obecnie jednoznaczną chronologię wału (materiały i dokumentacja z badań znajdują się w Instytucie Archeologii Uniwersytetu Mikołaja Kopernika i Wojewódzkim Urzędzie Ochrony Zabytków w Toruniu; Chęć 2009). 


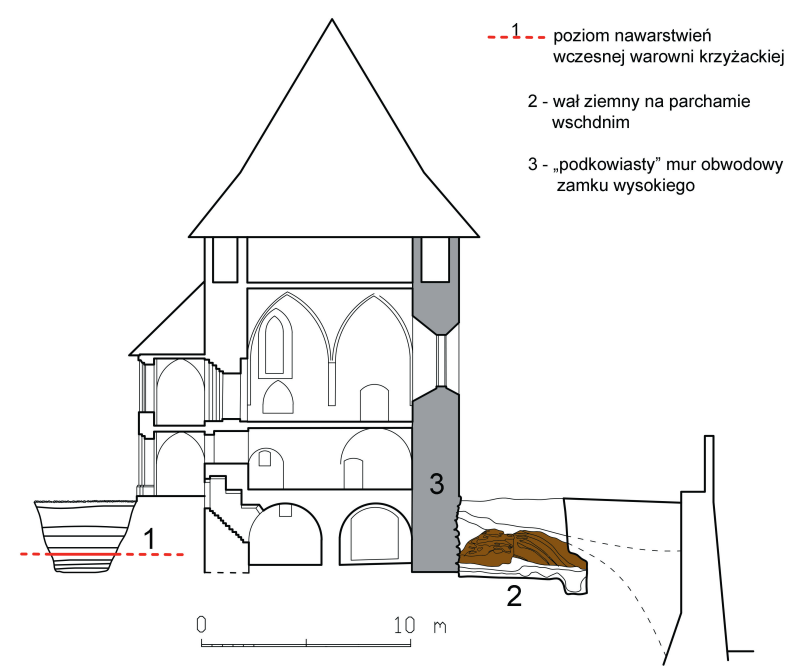

Ryc. 5. Toruń. Przekrój przez wschodni parcham i skrzydło z reliktami wału na międzymurzu (wg Chudziakowa, Kola 1974; Nawrocki 2005; rys. B. Wasik)

Fig. 5. Torun. Section of the eastern outer bailey and the wing with relics of rampart (after Chudziakowa and Kola 1974; Nawrocki 2005; drawing by B. Wasik)

strony największego zagrożenia (ryc. 3). Podobnie postąpiono w Słupie, budując wał od strony wysoczyzny na wewnętrznym członie założenia, najpewniej kolejny na obrzeżu członu zewnętrznego oraz podwójną fosę (ryc. 2). W Kałdusie mniejszą krzyżacką warownię odcięto od większej przestrzeni starego grodu trzema ciągami podwójnych częstokołów z wbitych ciasno pali. Od południowego wschodu fortyfikację tej warowni stanowił nadal zaadaptowany stary, potężny wał. Wzniesiona natomiast na tzw. surowym korzeniu warownia w Słoszewach otrzymała dookolny wał ziemny wzmocniony palisadą (ryc. 4). U podnóża od południa, wschodu i zachodu osłaniał ją drugi wał wydzielający fosę, łączącą się z przekopem odcinającym założenie od wysoczyzny morenowej (Kola 1991, s. 77, 80-81, 83-84, 86, 92, 213). Należy zauważyć, że na interesującym nas obszarze brakuje typowych dla Czech płaszczy kamiennych. Niewiele też wiemy na temat stosowania wzmocnień drewnianych stoków; zarejestrowano je jedynie w Grucie. W północnej części założenia wewnętrzny stok wału był tam wzmocniony drewnianą konstrukcją opartą na palach wbitych co 2,8-3,5 m w ziemię (Kola 1991, s. 83). Brak innych przykładów takich rozwiązań może jednak wynikać nie tyle z ich niestosowania, co ograniczonego i wycinkowego stanu badań poszczególnych obiektów. Sprawia to także, że nadal trudno scharakteryzować technikę budowy krzyżackich wałów.

Nieco więcej wiadomo odnośnie zabudowy wnętrz krzyżackich warowni drewniano-ziemnych. Wznoszono tam pojedyncze budynki, które opierały się o wały i często były z nimi sprzężone, niekiedy miały rozmiary dworów czy 
budynków zamkowych. W Słupie, wraz z nowym wałem, wzniesiono przyległy doń szachulcowy dom o wymiarach $14 \times 6,5 \mathrm{~m}$ (ryc. 2). Podobnie w Słoszewach znajdował się duży budynek szachulcowy o wymiarach $13 \times 7,5 \mathrm{~m} \mathrm{z}$ niewielkim aneksem na osi krótszego, północnego boku (ryc. 4). Od strony zbocza ściany wzmacniały duże słupy, co miało zabezpieczyć konstrukcję przed osunięciem. Budynek ów, podobnie jak w Słupie, związany był z wałem. Również w Grucie zabudowę stwierdzono na obrzeżu (północnym) majdanu; były to dwa mniejsze drewniane, zapewne zrębowe budynki o boku około $6 \mathrm{~m}$, ulokowane przy wale (Kola 1991, s. 91, 106-111). W Wieldządzu co prawda nie natrafiono na relikty zabudowy, ale w późnośredniowiecznych nawarstwieniach zarejestrowano gruz ceglany, zaprawę i polepę, co może świadczyć o tym, że przynajmniej częściowo była ona murowana (Matuszewska-Kola 1978, s. 228). W Grudziądzu negatyw ściany drewnianego budynku, który można łączyć z krzyżacką drewniano-ziemną warownią, zarejestrowano na terenie obecnego dziedzińca zamkowego (ryc. 6) (Wiewióra 2012, s. 108-109). Ponieważ nie jest znany układ tego pierwotnego założenia, nie można określić jakie miejsce w jego obrębie zajmował ów budynek, zwłaszcza, że nie jest także znany jego wymiar. W Toruniu natomiast, pod wschodnią częścią skrzydła południowego, odkryto konstrukcję wykonaną z kamieni bez użycia zaprawy, którą należy najpewniej interpretować jako podwalinę budynku szkieletowego (ryc. 7) (Chudziakowa, Kola 1974, s. 35-36). Nie ustalono jego wymiarów, ale zapewne wschodnią ścianą dotykał on do wału, gdyż znajdował się w jego bezpośrednim sąsiedztwie (ryc. 8). Poza wspomnianym budynkiem w obrębie dziedzińca zamkowego odkryto też drewniane relikty innych obiektów (Chudziakowa, Kola 1974, s. 37). Co do funkcji krzyżackiej zabudowy podpowiedzi udzielają źródła pisane. W dokumencie z 1263 roku biskup warmiński Anzelm udzielił odpustów, osobom angażującym się w podjętą przez komtura budowę nowej kaplicy na zamku w Toruniu (CDW, nr 45). Ponieważ informacja dotyczy wznoszenia nowej budowli, oznacza to, że w połowie XIII wieku musiała funkcjonować poprzednia kaplica. Ponieważ wspomniane wyżej relikty budynku na kamiennym fundamencie zlokalizowano pod późniejszą kaplicą, nie można wykluczyć pewnej kontynuacji tradycji miejsca, choć jest to tylko trudne do udowodnienia przypuszczenie. Kolejna interesująca wzmianka, rzucająca nieco światła na charakter zabudowy krzyżackich warowni tego okresu, dotyczy obiektu w Radzyniu Chełmińskim, który, podobnie jak Toruń, od połowy XIII wieku był siedzibą komturów (Jóźwiak 1997, s. 35, 46). W dokumencie z 1285 roku wymieniona jest kaplica oraz wnętrze pełniące funkcję refektarza ${ }^{6}$. Obecność

${ }^{6}$ Szerzej na ten temat - por. Jóźwiak, Trupinda 2012a, s. 297-299. Trudno się jednak zgodzić $\mathrm{z}$ autorami, że wzmianka ta dotyczy pomieszczeń w istniejącym do dziś murowanym zamku. Cechy jego architektury wskazują, że nie mógł on powstać tak wcześnie. Informację tą należy więc odnieść do funkcjonującej w Radzyniu od 2. ćwierci XIII wieku warowni krzyżackiej w typie zamku przejściowego. Ponieważ jej śladów brak na terenie murowanego zamku, należy przypuszczać, że funkcjonowała w miejscu wczesnośredniowiecznego grodu (Wasik 2015, s. 167, 175-177). 


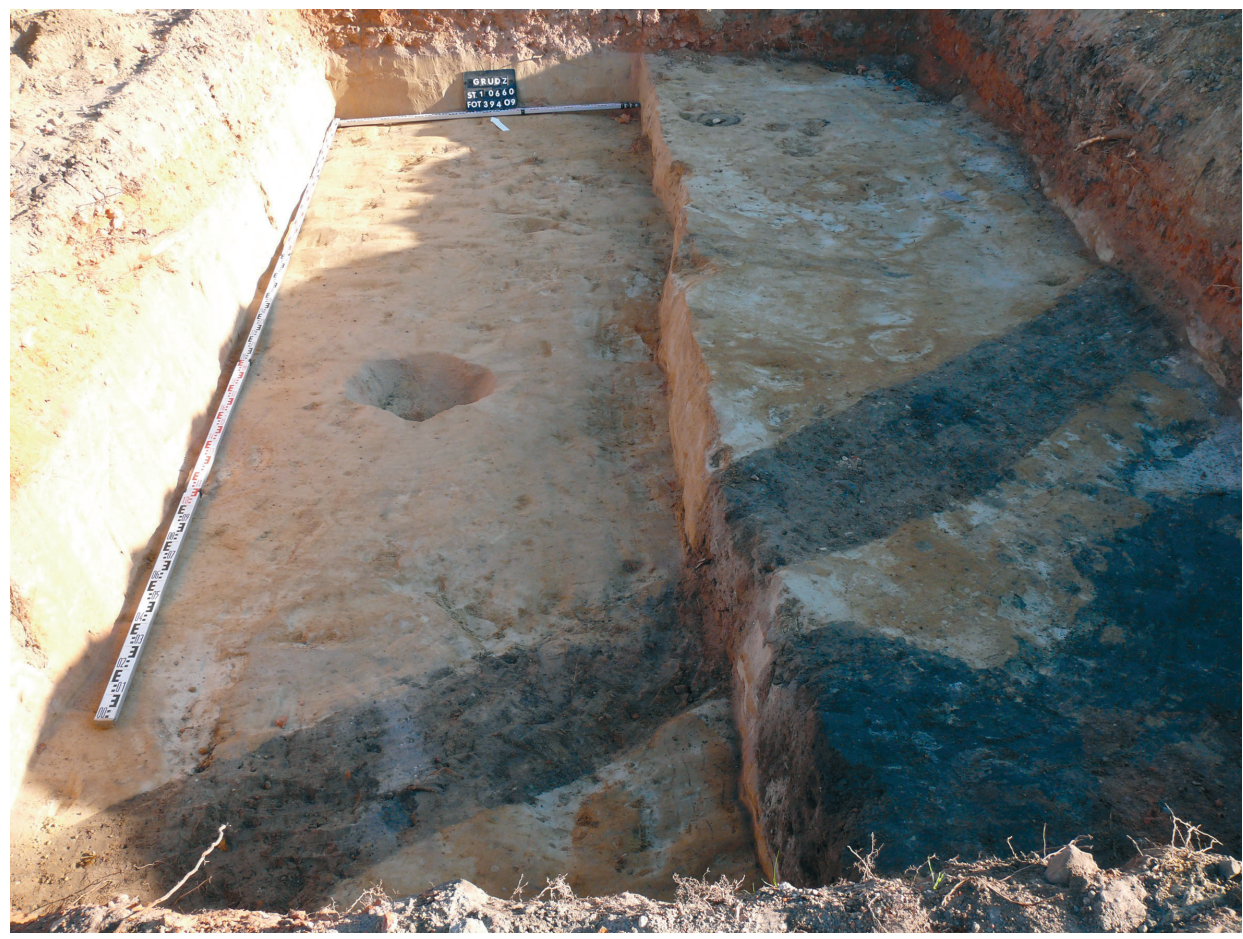

Ryc. 6. Grudziądz. Negatyw ściany późnośredniowiecznego budynku drewnianego (fot. M. Wiewióra)

Fig. 6. Grudziądz. Negatives of wall of a late medieval wooden building (photo M. Wiewióra)

kaplic nawet we wczesnych siedzibach krzyżackich nie powinna jednak dziwić, biorąc pod uwagę, że były one jedynymi obiektami wymaganymi i opisywanymi przez zakonne reguły (Jóźwiak, Trupinda 2012a, s. 39-41). Koresponduje to także z przekazem Piotra z Dusburga, informującego między innymi o modlitwach pobożnych braci w kaplicach warowni w Bałdze i Pokrzywnie (Dusburg 2004, s. 57). Obecność pomieszczeń jadalnych była natomiast konieczna dla zbiorowego funkcjonowania zgromadzenia braci-rycerzy. Te nowe spostrzeżenia pozwalają odrzucić stwierdzenie Mariana Arszyńskiego, który podważał wiarygodność przekazów krzyżackiego kronikarza, argumentując, że życie monastyczne w realiach wojen nie było możliwe (Arszyński 1995, s. 124). Zabudowa pierwszych warowni krzyżackich wykonywana była przede wszystkim z lekkich materiałów (drewniana i szachulcowa), co najlepiej oddaje informacja Piotra z Dusburga o rozbiórce w 1283 roku warowni Potterberg, której elementy przeniesiono i wykorzystano do budowy nowej siedziby w Gniewie (Dusburg 2004, s. 160).

Przynajmniej w niektórych przypadkach krzyżackie zamki typu przejściowego posiadały wieże, na co wskazują wzmianki w źródłach pisanych. W 1262 roku, 


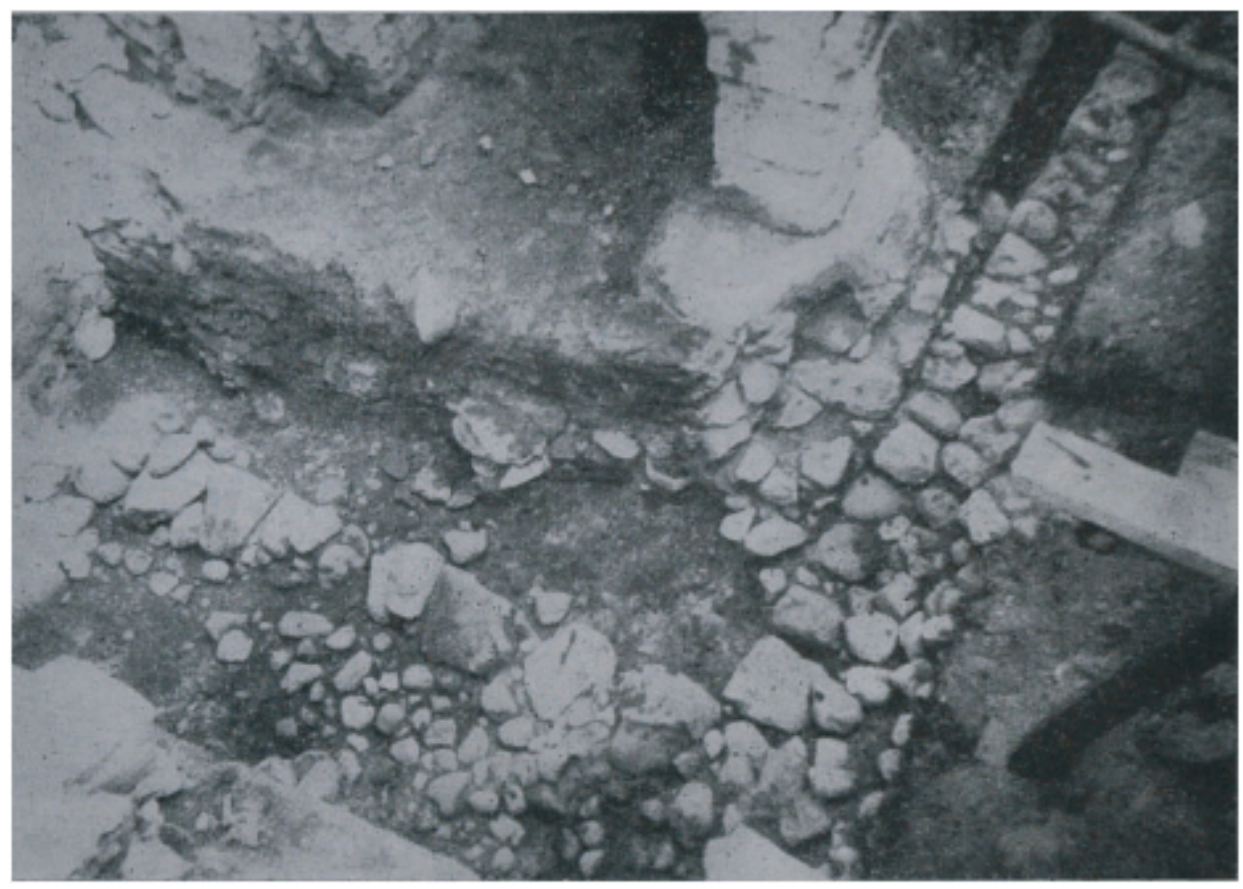

Ryc. 7. Toruń. Relikty kamienne odkryte pod wschodnią częścią skrzydła południowego (wg Chudziakowa, Kola 1974)

Fig. 7. Torun. Stone relics discovered under the eastern part of the southern wing (after Chudziakowa and Kola 1974)

podczas oblężenia przez Prusów zamku w Bierzgłowie, obrońcy schronili się w wieży, położonej zapewne w obrębie warowni (Dusburg 2004, s. 135). Interesujące informacje znajdują się też w źródłach z połowy XIII wieku, odnoszących się do położonej daleko od ziemi chełmińskiej Kłajpedy. Wynika z nich bowiem, że poza zasadniczym obiektem obronnym, na wyspie u ujścia wód Zalewu Kurońskiego do morza, znajdowała się jeszcze wieża (Jóźwiak 2015, s. 8). Niestety, trudno stwierdzić na ile powszechnie wznoszono w pobliżu warowni wieże, niezwiązane bezpośrednio z ich fortyfikacjami. Bez wątpienia jednak obiekty te budowano $\mathrm{z}$ drewna $\mathrm{w}$ konstrukcji szkieletowej lub innej, przypominały one najpewniej wieże znane z gródków stożkowatych. Być może z tego typu budowlami należy łączyć relikty szachulcowej wieży (dwóch faz) odkryte na przedzamczu, po wschodniej stronie starego zamku w Kwidzynie. Jednak z powodu braku ściślejszego datowania i wątłych przesłanek do interpretacji, nie ma pewności, czy można ją łączyć z wczesnym, drewniano-ziemnym okresem warowni i czy rzeczywiście była to wieża, jak sugerował Waldemar Heym (1933, s. 7-11).

Reasumując, krzyżackie warownie drewniano-ziemne z XIII wieku wznoszone były w warunkach poważnych przeobrażeń społeczno-gospodarczych, 
zachodzących na terenach zajmowanych przez Zakon. Fortyfikacje te, podobnie jak w Czechach i na Śląsku, miały pomagać w organizowaniu i pilnowaniu nowego osadnictwa i porządku społecznego, a także ułatwić ofensywną akcję podboju. Chętnie, choć nie zawsze, wznoszono je na zrębach opuszczonych wczesnośredniowiecznych grodów. Była to nieco odmienna sytuacja niż w Czechach, ale należy to tłumaczyć warunkami stanu wojny, wymagającymi pośpiechu. Przystosowanie do potrzeb Krzyżaków istniejących już (nawet opuszczonych i zniszczonych) grodów pochłaniało bez wątpienia mniej sił, a do tego zajmowały one dogodne pod względem obronnym i strategicznym miejsca. Fortyfikacje krzyżackich warowni stanowiły wały, z którymi sprzężone były pojedyncze budynki. Funkcjonalnie odpowiadały one nowym realiom i potrzebom Krzyżaków, mieszcząc kaplice i pomieszczenia potrzebne do ich wspólnotowego funkcjonowania. Widoczne różnice konstrukcyjne, jak brak kamiennych płaszczy na wałach należy tłumaczyć chociażby zatrudnianiem lokalnych robotników, nawykłych do tradycyjnych technik budowy. Biorąc więc pod uwagę powyższe cechy i uwarunkowania, obiekty te odpowiadają definicji zamków typu przejściowego. Należy dodać, że wielu przybyłych do Prus Krzyżaków musiało znać rozwiązania czeskie, gdyż rycerzy zakonnych i Koronę Św. Wacława łączyły silne więzi polityczne. Ponadto posiadłości pruskie i czeskie Krzyżaków powiązane były administracyjnie w początkowym okresie podboju. Od 1233 roku mistrzowi krajowemu Prus podlegały krzyżackie prowincje Czech i Moraw; funkcję tę sprawował wówczas Herman Balk (Jóźwiak 2001, s. 22-23). W świetle tych rozważań nie można zgodzić się z opinią M. Arszyńskiego, jakoby wczesne warownie krzyżackie należało zaliczyć do „prymitywnych założeń mieszkalno-obronnych, nawiązujących materiałem i kształtem do sięgających daleko wstecz tradycji miejscowego budownictwa grodowego" (Arszyński 2000, s. 30), gdyż wpasowywały się one w przekształcenia w architekturze zamkowej, następujące w XIII wieku w Europie Środkowej.

Jak wynika z relacji Piotra z Dusburga, opisywane wyżej zamki typu przejściowego przechodziły często z rąk do rąk i musiały być odbudowywane, jak Brandenburg lub były opuszczane, jak Spittenberg (Dusburg 2004, s. 119-121, 131). Wydarzenia pierwszego powstania pruskiego, kiedy w 1243 roku Krzyżacy utrzymali się tylko w Elblagu, Bałdze, Toruniu, Starogrodzie i Radzyniu Chełmińskim (Dygo 2008, s. 69), zapewne spowodowały, że przystąpiono do wznoszenia pierwszych murowanych obwarowań w Toruniu i prawdopodobnie w Starogrodzie.

Od czasów publikacji pracy Karla Heinza Clasena (1927, s. 13-50) krzyżackie zamki nieregularne (m.in. Toruń, Starogród, Pokrzywno, Grudziądz, Bierzgłowo) umieszczano w szeregu rozwojowym obronnego budownictwa zamkowego (Torbus 1998, s. 55-84). Nie przykładano jednak wystarczającej wagi do złożonego charakteru tych wznoszonych w wielu fazach budowli. W efekcie ich dwu-, trzyskrzydłowy rzut traktowano jak formę pierwotną i analizowano w kontekście 
XIII-wiecznego budownictwa zamkowego. W rzeczywistości obraz tych obiektów jest jednak o wiele bardziej złożony.

Z powodu niezachowania się obiektu w Starogrodzie i jego słabego stanu badań nie ma pewności co do formy inwestycji (Torbus 1998, s. 337). W Toruniu za najstarszy element murowany uchodzi powszechnie kamienny mur wzniesiony od wschodu, u podnóża starego wału i na północ od niego (ryc. 8, 9). W jego linii znajdowała się wieża bramna, później zamurowana. Mur ten biegł pierwotnie w kierunku południowym dalej niż obecnie, ale jego zasięg nie jest znany (Nawrocki 2005, s. 19). Bronił więc dostępu do zamku od strony podmokłej doliny i od przestrzeni nie osłoniętej przez formujące się Stare Miasto Toruń. Według Jerzego Frycza miał on zostać wzniesiony w latach 1236-1240 (Frycz 1963, s. 85; 1986, s. 32). Wydaje się jednak wątpliwe, aby tak wcześnie przystąpiono do budowy muru, gdyż w pierwszych latach funkcjonowania warownia była drewniano-ziemna. Jak wiadomo, komturstwo w Toruniu powołano między 1248 a 1251 rokiem (Jóźwiak 1997, s. 35), natomiast z 1255 roku pochodzi zapis dotyczący budowy muru i wieży (Frycz 1963, s. 85). Być może należy więc go utożsamiać z kamiennym murem i wieżą bramną ${ }^{7}$ Inwestycję tę trzeba łączyć $\mathrm{z}$ faktem, że wówczas nadano warowni rangę siedziby komtura. Najprawdopodobniej w tym czasie przystąpiono także do wznoszenia niektórych odcinków kurtyny obwodowej zamku wysokiego (domu konwentu) - środkowego fragmentu muru południowego i przyziemnej, południowej części kurtyny wschodniej (ryc. 8). W drugim etapie wymurowano do końca obwód domu konwentu na planie podkowy, łącząc wcześniej wykonane odcinki (ryc. 5). Wąskoprzestrzenne rowy fundamentowe pod ten mur wykopano po wewnętrznej stronie starszego wału ziemnego, zapewne częściowo go niwelując (Nawrocki 2005, s. 9-10; Wasik 2016, s. 246). Nie należy jednak zbyt pochopnie wnioskować, że podkowiasty plan zamku był wynikiem pierwotnego układu wału. Pouczający jest tu przykład krzyżackiej siedziby w Beuggen (Niemczy; ryc. 17), która została wzniesiona na tzw. surowym korzeniu w połowie XIII wieku na planie półokręgu (Liessem 2004, s. 106). Niemniej lokalizacja zbudowanego na początku kamiennego odcinka muru południowego zamku wysokiego w Toruniu zdaje się potwierdzać podkowiasty przebieg pierwotnego wału. Odcinek ten zamykałby lukę w fortyfikacji od strony rzeki. Stare wały były wówczas jeszcze do pewnego stopnia na pewno wykorzystywane. Zniwelowany wał wschodni stał się przedmurzem nowego obwodu, tak więc wzmocniony na przykład palisadą mógł nadal pełnić funkcję zewnętrznej fortyfikacji ${ }^{8}$.

Wznosząc kurtynę obwodową domu konwentu w Toruniu planowano już w jakiejś postaci budowę skrzydła południowego i zabudowę od wschodu, nie wykonano ich jednak wówczas, a w przyszłości zmieniano plany. W pierwszej

\footnotetext{
${ }^{7}$ Inna wieża, którą by można łączyć z tym okresem budowy zamku, w świetle aktualnego stanu badań nie jest znana.

8 Rozwiązanie takie nasuwają przykłady zamków śląskich - w Opolu i Legnicy (Rajski 2013, s. 241).
} 


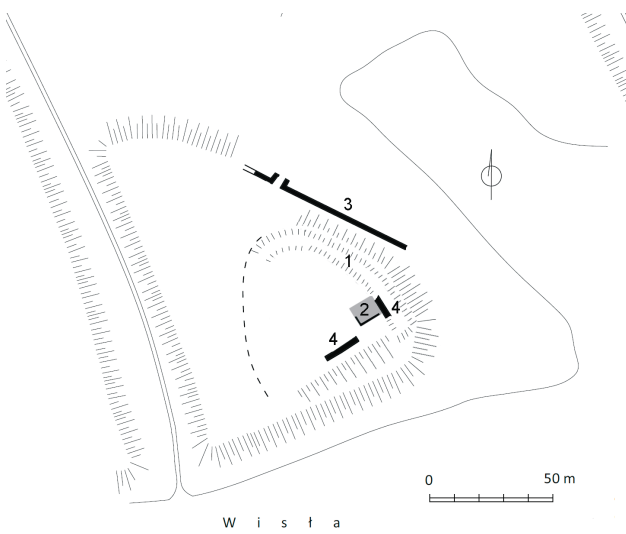

połowa XIII w.

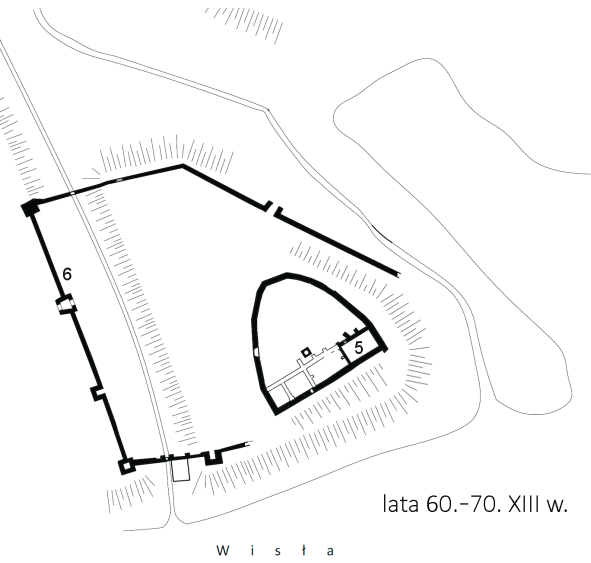

Ryc. 8. Toruń. Rzut pierwszych faz budowlanych zamku murowanego: 1 - wał, 2 - budynek na kamiennej podwalinie, 3 - mur kamienny, 4 - pierwsze odcinki kurtyny obwodowej (,podkowiastej”) zamku wysokiego, 5 - wschodnia (pierwotna) część skrzydła południowego, 6 - ceglany mur przedzamcza górnego (ryc. B. Wasik)

Fig. 8. Torun. Plan of first construction phases of mortared castle: 1 - rampart, 2 - building on a stone sill, 3 - stone wall, 4 - first sections of curtain wall ('horseshoe') of the high castle, 5 - eastern (original) part of the southern wing, 6 - brick wall of high outworks (drawing by B. Wasik)

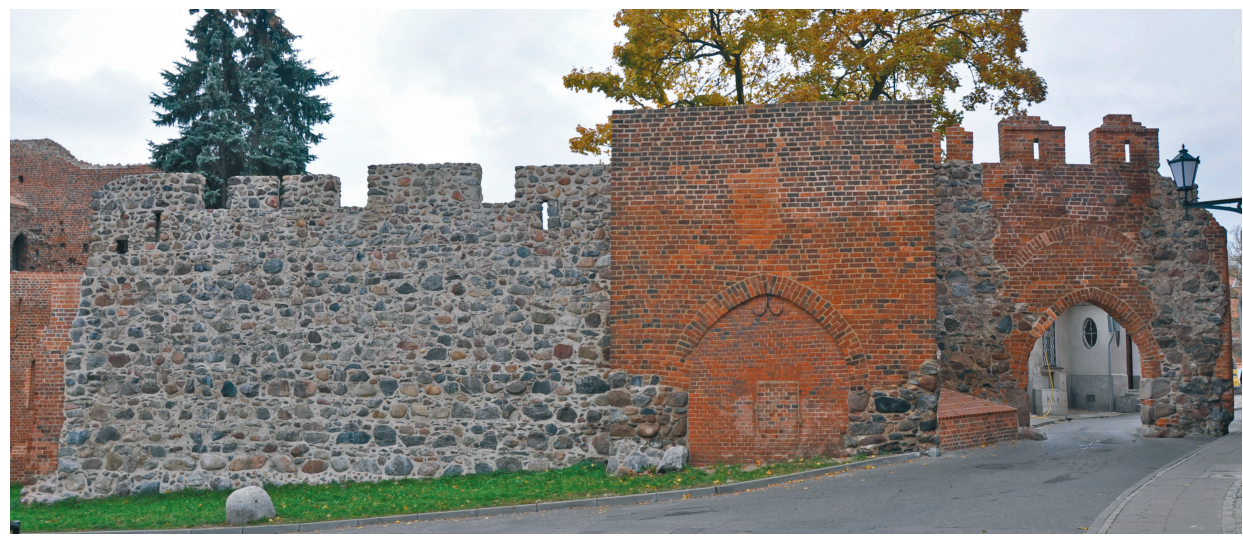

Ryc. 9. Toruń. Mur kamienny z połowy XIII wieku (fot. B. Wasik)

Fig. 9. Torun. Stone wall from the mid-13 $3^{\text {th }}$ century (photo B. Wasik)

kolejności wymurowano pomieszczenie przyziemia skrzydła południowego (ryc. 8), co być może należy łączyć z rozpoczęciem budowy wspominanej już nowej kaplicy w latach 60 . XIII wieku. Był to niewielki, wzmocniony przyporami, prostokątny budynek (Nawrocki 2005, s. 11; Wasik 2016, s. 246-248).

$\mathrm{Na}$ dalszych działaniach budowlanych odbiły się bez wątpienia problemy związane z tłumieniem drugiego powstania pruskiego. Do kolejnych inwestycji 
w regionie Zakon przystąpił zapewne w momencie jego przygaszania. Tak więc najpewniej na lata 70. XIII wieku należy datować początki przekształcania zamków typu przejściowego przez wznoszenie pierwszych elementów murowanych - w Pokrzywnie, Grudziądzu i Bierzgłowie (Wasik 2016, s. 261, 254, 265-266). Co ważne, wiązało się to z utworzeniem tam wówczas centrów nowych komturii (Jóźwiak 1997, s. 91, 103; Jóźwiak, Trupinda 2012b, s. 50).

W tym okresie w Pokrzywnie (I faza zamku murowanego), w północnym narożniku zamku wysokiego, wzniesiono kamienny budynek na planie krótkiego prostokąta o wymiarach około $20 \times 11,5 \mathrm{~m}$ (ryc. 10, 11). Posadowiono go tak, że musiał zostać wkopany w stary wał. Budynek był pomyślany jako samodzielnie stojący, na co wskazuje rozmieszczenie okien w ścianie południowo-zachodniej i południowo-wschodniej oraz lokalizacja wejścia do piwnicy od południowego wschodu. Wynika stąd, że na tym etapie nie planowano sąsiednich skrzydeł, gdyż podczas ich budowy konieczne było zamurowanie otworów i wykonanie nowego wejścia. Pomieszczenie to nie było zresztą całkowicie zagłębione w ziemi i miało raczej charakter sutereny ${ }^{9}$. Rzut budynku może sugerować, że w pierwotnych planach miał on mieć formę wieżową. Niemniej w interesującej nas fazie budowy zamku zrealizowano najprawdopodobniej jedynie kamienny poziom piwnic i parteru. Przyjmuje się, że na wzniesionym później piętrze mieściła się kaplica (Rzeczkowska-Sławińska 1983, s. 18; Torbus 1998, s. 402). Nie można wykluczyć, że przed wykonaniem ceglanej górnej kondygnacji podczas rozbudowy zamku w końcu XIII wieku piętro istniało w formie szkieletowej.

W opisywanym okresie rozpoczęto także budowę kamiennych partii murów obwodowych (Clasen 1927, s. 39; Sławińska 1969, s. 239-240; Rzeczkowska-Sławińska 1983, s. 18). W kurtynie północno-wschodniej kamienny cokół jest przerwany na wysokości skrzydła środkowego (zaraz na południe od kamiennego budynku), w związku z czym nie wiadomo, czy budowę obwodu rozpoczęto jednocześnie $\mathrm{z}$ opisanym gmachem. Maria Rzeczkowska-Sławińska interpretowała tę przerwę jako pierwotny wjazd do zamku, co bez badań archeologicznych trudno ocenić. Stan zachowania murów nie pozwala także jednoznacznie stwierdzić, czy budowę prowadzono jednocześnie na całym obwodzie. Najprawdopodobniej jednak w opisywanym okresie rozpoczęto zastępowanie dawnych wałów fortyfikacjami murowanymi, poczynając od najbardziej narażonej strony wschodniej (Wasik 2016, s. 261-263).

Również w Grudziądzu w latach 70.-80. XIII wieku wzniesiono pojedynczy murowany budynek (ryc. 12). Podobnie jak w Pokrzywnie usytuowano go w narożniku założenia, od strony najłatwiejszego dostępu. Był to jednak większy niż w poprzednim zamku gmach, mierzący około $34 \times 15 \mathrm{~m}$, o ścianach dochodzących na poziomie piwnic nawet do $4 \mathrm{~m}$ grubości. Przekonuje to, że już w pierwotnych

${ }^{9}$ Niestety, z powodu braku niwelacji i ograniczonego stanu badań trudno porównać poziom ówczesnego dziedzińca z głębokością posadowienia piwnicy. 


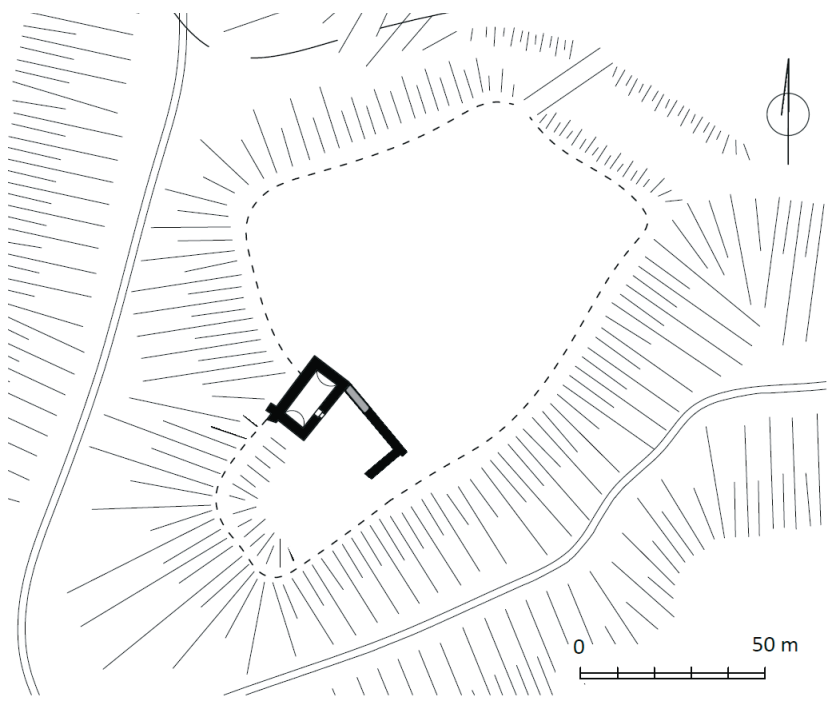

Ryc. 10. Pokrzywno, pow. Grudziądz. Rzut zamku z lat 70.-80. XIII wieku (ryc. B. Wasik) Fig. 10. Pokrzywno, district. Plan of the castle from the 1270s-1280s (drawing by B. Wasik)

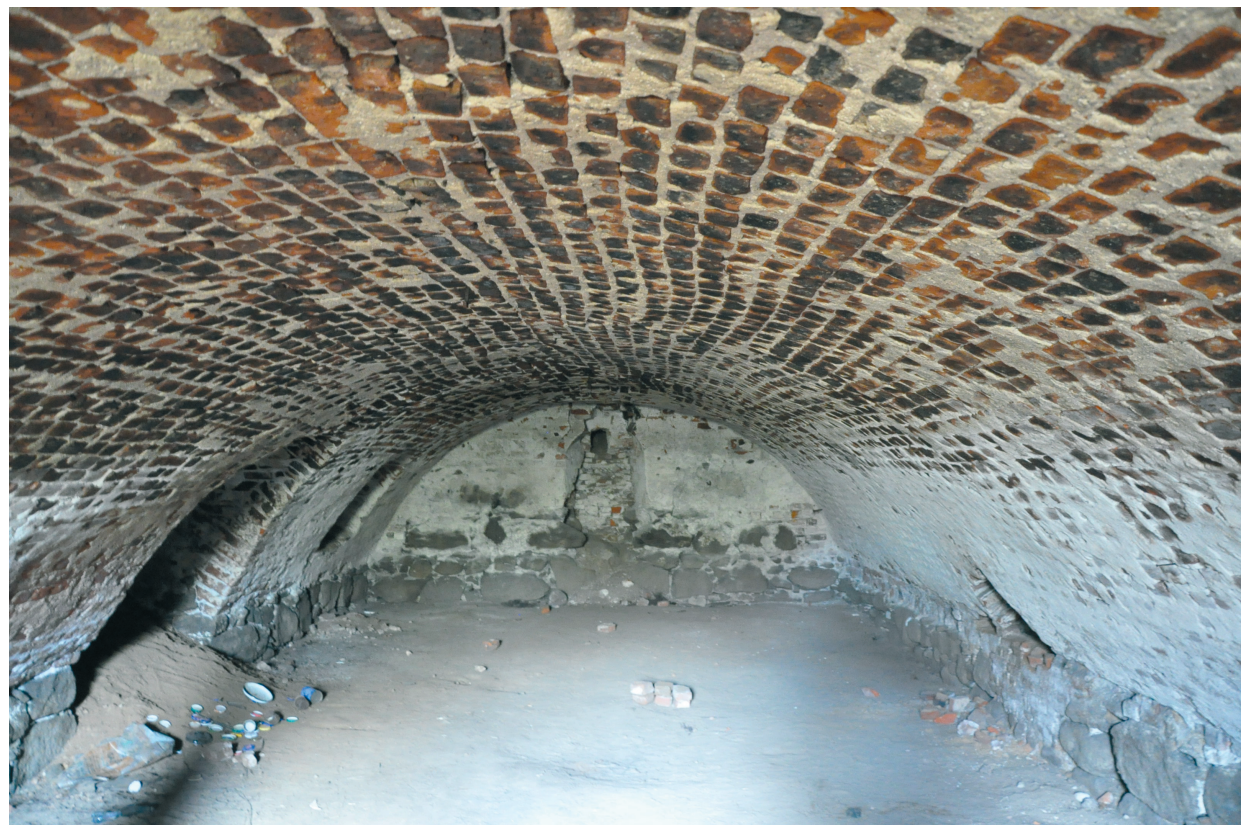

Ryc. 11. Pokrzywno, pow. Grudziądz. Piwnica budynku z lat 70.-80. XIII wieku (fot. B. Wasik)

Fig. 11. Pokrzywno, district. Basement of a building from the 1270s-1280s (photo B. Wasik) 
Ryc. 12. Grudziądz. Rzut zamku z lat 70.-80. XIII wieku (ryc. B. Wasik)

Fig. 12. Grudziądz. Plan of the castle from the $1270 \mathrm{~s}-1280 \mathrm{~s}$ (drawing by B. Wasik)

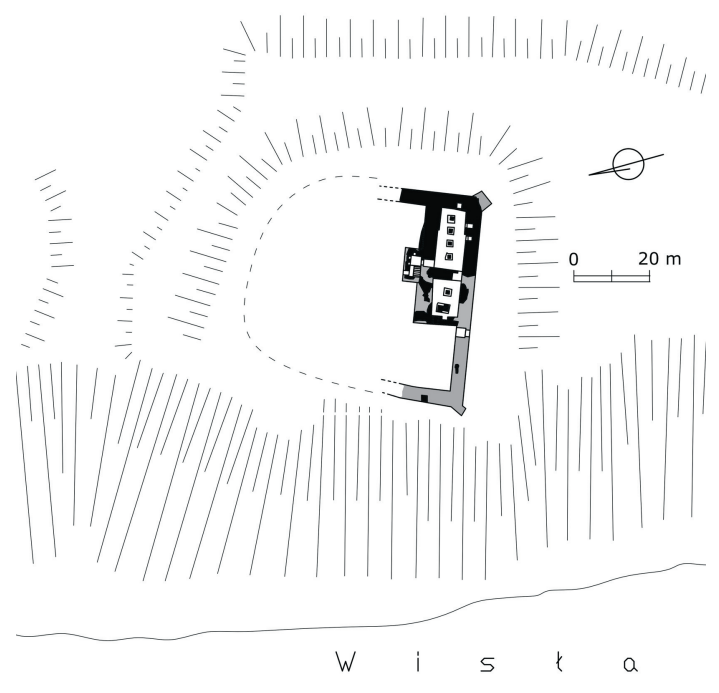

planach miał to być wysoki budynek. Obejmował on dwa pomieszczenia wschodnie przyszłego skrzydła południowego (głównego), przy czym jego późniejsze przedłużenie w kierunku zachodnim nie było wówczas planowane i jest węższe. Podobnie jak w Pokrzywnie, nad jednym z wzniesionych w opisywanym okresie wnętrz, funkcjonowała później kaplica, przy czym w interesującej nas fazie wymurowano jedynie piwnice i przyziemie (Zimnowoda-Krajewska 2012, s. 154-155; Wasik 2016, s. 254-255). Równolegle z budową tego założenia przystąpiono do wznoszenia muru obwodowego, jednak na tym etapie wymurowano jedynie krótki odcinek od wschodu i prawdopodobnie od południa ${ }^{10}$, a więc od strony najłatwiej dostępnej (Wasik 2014, s. 101).

Ze względu na brak badań archeologicznych określenie wyglądu pierwszej fazy zamku w Bierzgłowie nie jest łatwe. W związku z tym nie ma też pewności, czy murowany zamek wzniesiono rzeczywiście w miejscu warowni drewniano-ziemnej, choć wydaje się to bardzo prawdopodobne. Istotnych przesłanek dostarcza jednak analiza rzutu zamku na poziomie piwnic. Północno-zachodni narożnik domu konwentu zajmowało niegdyś krótkie skrzydło, które zostało w latach 30. XIX wieku rozebrane. Co istotne, mierzący około $11 \times 22 \mathrm{~m}$ gmach mieścił kaplicę (Steinbrecht 1888, s. 13). Zachodni odcinek ściany tego budynku jest nadal czytelny na rzucie piwnic zamku. Ściana ta przebiega równolegle do północno-wschodniej kurtyny domu konwentu i jest grubsza od gotyckich ścian działowych skrzydła zachodniego. Regularne skrzydło zachodnie jest od interesującego nas budynku oddzielone małym pomieszczeniem o rzucie w kształcie trapezu. Na

${ }^{10}$ Przemawia za tym znaczna różnica głębokości fundamentowania oraz masywności południowego odcinka kurtyny wschodniej w porównaniu do jej północnej części. Niestety, część południowo-zachodnia obwodu domu konwentu nie zachowała się, w związku z tym nie można określić, jak duży odcinek fortyfikacji na tym etapie zbudowano. 
Ryc. 13. Bierzgłowo, pow. Torun. Hipotetyczny rzut zamku z lat 70.-80. XIII wieku (ryc. B. Wasik)

Fig. 13. Bierzgłowo, district. Hypothetical plan of the castle from the $1270 \mathrm{~s}-1280 \mathrm{~s}$ (drawing by B. Wasik)

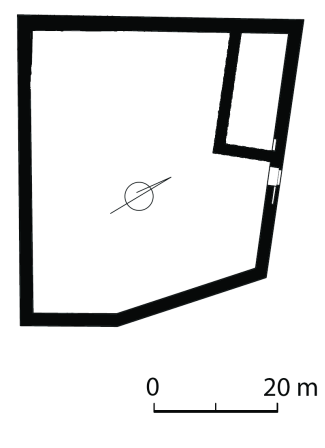

podstawie powyższych cech można wywnioskować, że skrzydło mieszczące kaplicę powstało w pierwszej fazie budowy murowanego zamku, a wczesną jego chronologię potwierdza profilówka służki, pochodząca z kaplicy i cechująca się dużymi odstępami między wiązkami o formie półwałków ${ }^{11}$. Za tą kolejnością budowy przemawia także analiza etapów wznoszenia wyższych, ceglanych partii murów (Pawłowski, Wierzbicki, Markowska 1984). Tak więc pierwsze założenie murowane w Bierzgłowie składało się z prostokątnego budynku w jego narożniku, znajdującym się od strony przedzamcza oraz z muru obwodowego (ryc. 13). W przypadku tego ostatniego, z powodu braku badań archeologicznych, nie da się określić, czy wzniesiono wówczas cały obwód, czy tylko jego cześć (Wasik 2016, s. 265-266).

Podsumowując, należy zauważyć, że przekształcanie drewniano-ziemnych zamków typu przejściowego w murowane następowało poprzez stawianie pojedynczych murowanych budynków i zastępowanie odcinków fortyfikacji ziemnych murowanymi. Należy zwrócić uwagę, że w obiekty murowane przebudowywano te zamki typu przejściowego, które stawały się centrami nowych komturii. Nie było to jednak regułą i w niektórych ośrodkach, jak na przykład w Radzyniu Chełmińskim, siedzibami komturów były wówczas nadal obiekty drewniano-ziemne. W Toruniu, gdzie przystąpiono do inwestycji wcześniej, bo już około połowy XIII wieku, w pierwszej kolejności zaczęto wzmacniać obronę przez budowę murów obronnych od łatwo dostępnych kierunków, co należy łączyć z ciężkimi doświadczeniami pierwszego powstania pruskiego. Dopiero w połowie lat 60. XIII wieku przystąpiono do budowy murowanego budynku, który zastąpił stary o drewnianej konstrukcji. We wznoszonych w latach 70.-80. XIII

${ }^{11}$ Detal ten zadokumentowano około 1900 roku, a rysunek opublikował Tomasz Torbus (1998, s. 368 , ryc. 20 ). 
wieku zamkach w Pokrzywnie, Grudziądzu i Bierzgłowie najpierw wzniesiono pojedyncze murowane budynki, które lokalizowano od strony najłatwiej dostępnej (czołowej); poza funkcjami użytkowymi pełniły one także zadania obronne. Jak najlepiej widać to na przykładzie Pokrzywna, nie planowano wówczas budowy skrzydeł zamkowych. Równocześnie przystępowano do budowy murów obwodowych (przede wszystkim od strony narażonej na zagrożenie), zastępujących stare wały. Opisany proces budowy wpasowuje się w typowy dla XIII wieku sposób postępowania; wymienić tu można chociażby pierwsze zamki śląskie - Legnicę i Opole (Boguszewicz 1998, s. 98-99, 103; Kajzer, Kołodziejski, Salm 2001, s. 32-34; Chorowska 2003, s. 55).

Interesujący jest fakt, że we wszystkich opisywanych założeniach miejsce posadowienia pierwotnego budynku murowanego odpowiadało przyszłej lokalizacji kaplicy. Należy jednak zaznaczyć, że na tym etapie mieszczące ją murowane pierwsze piętra nie powstały. Wykonano je w kolejnych fazach budowy, następujących już według innej koncepcji. Biorąc pod uwagę wspomnianą wyżej wagę kaplicy dla zgodnego z regułą życia Krzyżaków, wydaje się jednak, że nie jest to przypadek i że budynki te wznoszono z myślą o lokalizacji kaplicy, ale nie tylko. Tych pierwszych budynków nigdy nie ukończono zgodnie z pierwotną koncepcją, choć nie można wykluczyć, że w niektórych przypadkach (Pokrzywno) już w tym okresie wykonano piętro z materiałów nietrwałych. Poza opisanymi budynkami murowanymi, w obrębie warowni zapewne funkcjonowały jeszcze stare obiekty wzniesione z drewna. W tym świetle wczesny murowany zamek krzyżacki rysuje się jako nieregularne założenie o murowanym obwodzie zastępującym starsze fortyfikacje, z pojedynczym budynkiem murowanym, mieszczącym najważniejsze dla braci-rycerzy pomieszania oraz zapewne nieregularnie rozmieszczone budynki drewniane.

Przedstawiony powyżej typ zabudowy XIII-wiecznych pierwszych murowanych warowni krzyżackich nie funkcjonował jednak wszędzie. Interesująco w świetle ostatnich badań Sławomira Jóźwiaka rysuje się wczesna warownia murowana w Kłajpedzie. Z dokumentu wystawionego w 1290 roku wynika, że posiadała ona wówczas mur obwodowy w rzucie czworoboczny (Jóźwiak 2015, s. 9). Informacja ta nasuwa skojarzenie z XIII-wiecznymi warowniami sąsiedniego państwa Kawalerów Mieczowych. Były to warownie obwiedzione murem obronnym o obrysie regularnym lub nieregularnym (w zależności od położenia), z drewnianą zabudową wewnętrzną (Ose 2004, s. 122-125). Ze względu na bezpośrednie sąsiedztwo Kłajpedy z obszarem Inflant można się domyślać, że założenia z dawnego państwa Kawalerów Mieczowych miały genetyczny wpływ na układ pierwotnego zamku w Kłajpedzie. Zatem jest to założenie odmienne od przedstawionych wyżej przykładów z ziemi chełmińskiej.

W starszej literaturze analogii do nieregularnych zamków krzyżackich w Prusach poszukiwano wśród siedzib rycerskich z obszarów wschodnich Niemiec 
i Turyngii (Kutzner 1995, s. 44; Arszyński 2010, s. 30). Należy jednak zwrócić uwage na XIII-wieczne siedziby komandorii krzyżackich w Niemczech i Czechach. Stanowiły je zazwyczaj nieregularne założenia, mieszczące kilka różnie rozmieszczonych murowanych budynków (np. w Pradze, Miletinie, Koblencji i Beuggen) (ryc. 14, 15, 17). Jednym z nich była standardowo kaplica. W niektórych, na przykład w Koblencji i Beuggen, znajdowały się także wieże mieszkalne (Durdík 2004, s. 48-52; Liessem 2004, s. 104-110). Szczególnie interesująca jest wieża w obrębie komandorii w Koblencji (ryc. 16), gdyż mieściła reprezentacyjne wnętrza $^{12}$ (Liessem 1996, s. 51-52). Podobnie w świetle nowszych badań prezentuje się siedziba kawalerów mieczowych z początku XIII wieku w Rydze; tworzyły ją nieregularnie rozmieszczone budynki i kaplica (Ose 2004, s. 120-122).

Przytoczone obiekty nie miały jednak zazwyczaj tak warownego charakteru jak pruskie, co wynikało z sytuacji politycznej. Warto zwrócić uwagę na zamek Bradlo w Czechach (ryc. 18), wzniesiony przez Krzyżaków w końcu XIII lub na przełomie XIII i XIV wieku. Było to założenie nieregularne z murem obronnym wzniesionym z kamieni bez użycia zaprawy. Przy obwodzie stała wieża mieszkalna w rzucie kwadratowa, której przyziemie wzniesiono również z kamieni bez zaprawy, a wyższe kondygnacje w technice szachulcowej. Poza nią przy murze znajdowały się jeden mały budynek murowany i zapewne pomocnicze drewniane (Durdík 2000, s. 79). Widać tu więc zbliżoną koncepcję organizacji przestrzeni i zabudowy, jak w przypadku opisywanych zamków z ziemi chełmińskiej.

$\mathrm{Na}$ koniec należy jeszcze wspomnieć o warunkach, w jakich te warownie realizowano, gdyż może zastanawiać ich skromna, w porównaniu do późniejszych, forma. Nie powinno to jednak dziwić, bowiem duże inwestycje budowlane wymagały odpowiednio rozwiniętej infrastruktury, gospodarki i administracji, które to w 2. i 3. ćwierci XIII wieku w Prusach nie osiągnęły jeszcze odpowiedniego poziomu. Był to czas kiedy Krzyżacy dopiero budowali podstawy swojego prężnie działającego w XIV wieku państwa. Do lat 80. XIII wieku środki Zakonu pochłaniane były przez nieustanne wojny. Brakowało także specjalistów, których na podbijanym terenie nie było. Dopiero wraz ze stabilizacją kraju i rozwojem osadnictwa od ostatniej ćwierci XIII wieku możliwe było powstanie odpowiedniego zaplecza, co zaowocowało rozkwitem budownictwa ceglanego na przełomie XIII i XIV wieku (Herrmann 2007, s. 290; Arszyński 2010, s. 11, 14; Czaja 2013, s. 85-86; Wasik 2016, s. 317-318).

Przedstawione powyżej przemiany krzyżackiego budownictwa zamkowego na ziemi chełmińskiej w XIII wieku wskazują, że były one bardziej złożone niż dotąd sądzono. Początkowo Krzyżacy wznosili liczne warownie drewniano-ziemne (zamki typu przejściowego), których cześć powstawała na zrębach starych grodów. Miały one strzec nowych zdobyczy, kiełkującego osadnictwa i nowego

${ }^{12}$ Wieża ta nie została wzniesiona przez Krzyżaków, ale otrzymali ją i przebudowali w 2. ćwierci XIII wieku. Piwnica i parter posiadały sklepienia, które zostały przebudowane w późnym średniowieczu. 


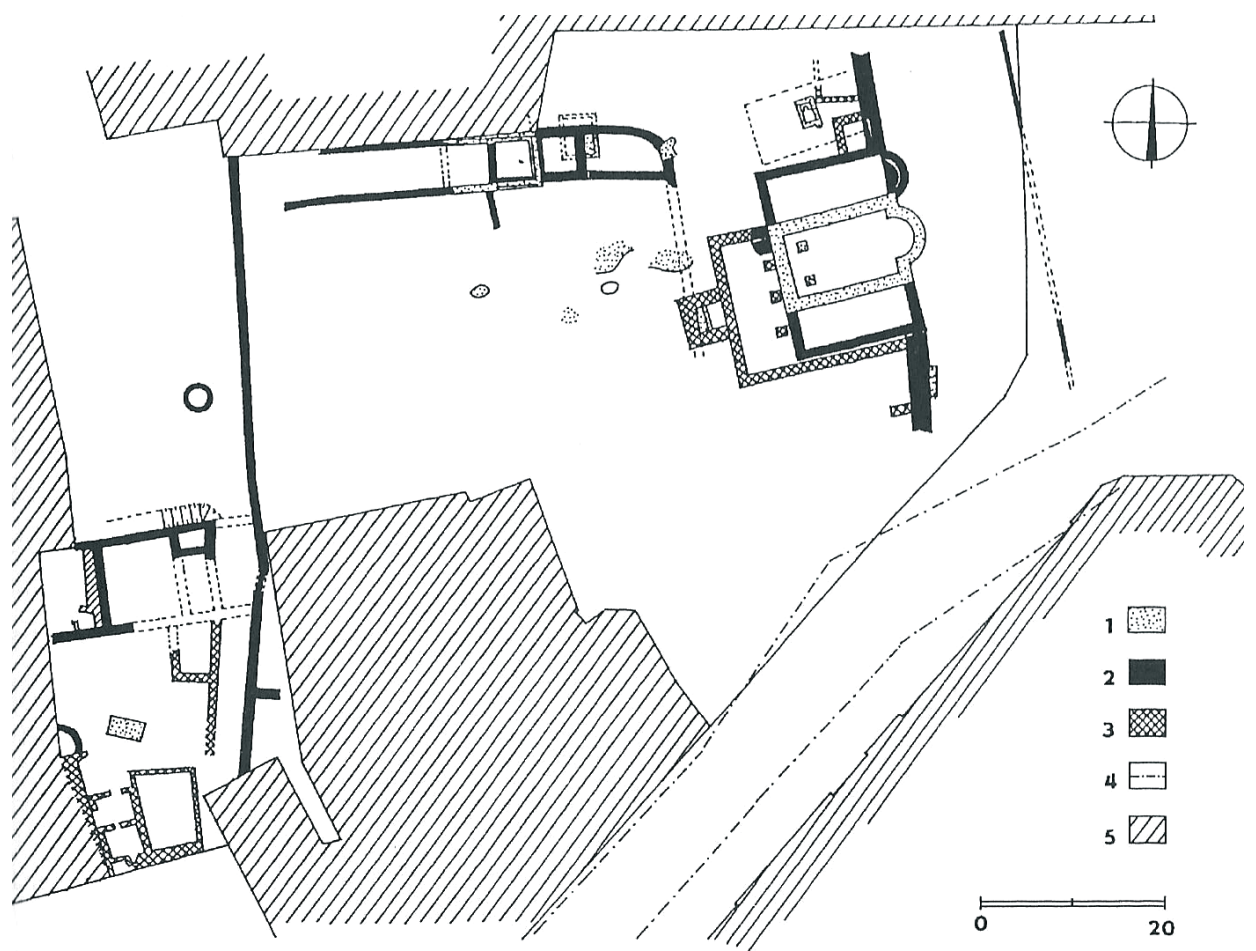

Ryc. 14. Praga, Czechy. Rzut komandorii krzyżackiej: 1 - zabudowa z XII i początku XIII wieku (przedkrzyżacka), 2 - zabudowa komandorii z połowy XIII wieku, 3 - rozbudowa komandorii w XIV wieku, 4 - pierwotny przebieg ulicy, 5 - młodsza zabudowa (wg Durdík 2004)

Fig. 14. Prague, Bohemia. Plan of the Teutonic Order's commandry: 1 - buildings from the $12^{\text {th }}$ and the early $13^{\text {th }}$ century (pre-Teutonic), 2 - buildings of the commandry from the mid- $13^{\text {th }}$ century, 3 - extension of the commandry in the $14^{\text {th }}$ century, 4 - original course of the street, 5 - younger buildings (after Durdík 2004)
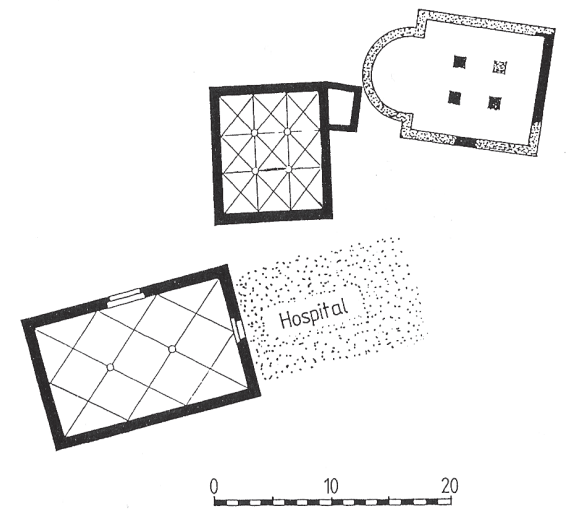

Ryc. 15. Koblencja, Niemcy. Rzut budynków krzyżackiej komandorii z połowy XIII wieku (wg Liessem 1996)

Fig. 15. Koblenz, Germany. Plan of buildings of the Teutonic Order's commandry from the mid- $13^{\text {th }}$ century (after Liessem 1996) 
Ryc. 16. Koblencja, Niemcy. Przekrój wieży mieszkalnej (Westbau) komandorii krzyżackiej (wg Liessem 1996)

Fig. 16. Koblenz, Germany. Section of tower house (Westbau) of the Teutonic Order's commandry (after Liessem 1996)

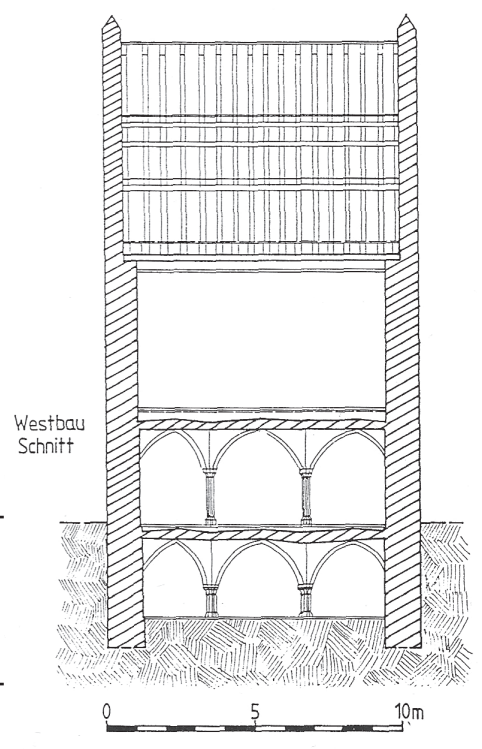

Ryc. 17. Beuggen, Niemcy. Rzut komandorii krzyżackiej z połowy XIII wieku: I - pierwotny budynek główny (wieża mieszkalna), II - Brama Górna, III - Brama Dolna (wg Liessem 2004)

Fig. 17. Beuggen, Germany. Plan of the Teutonic Order's commandry from the mid- $13^{\text {th }}$ century: I - original main building (tower house), II - Upper Gate, III - Lower Gate (after Liessem 2004)

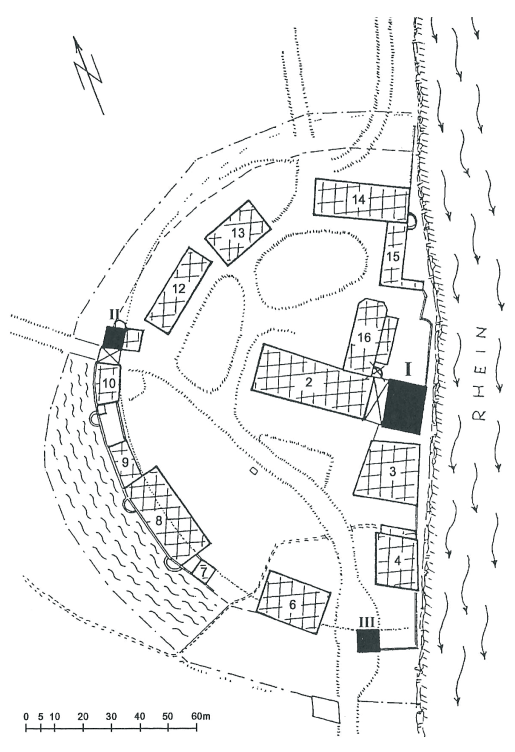

porządku społecznego. W kolejnych dekadach niektóre z nich stały się centrami komturii i obiekty z tej grupy jako pierwsze otrzymywały budowle murowane. Od końca XIII wieku nastąpiła rewolucja w krzyżackiej architekturze zamkowej, polegająca na zaadaptowaniu kasztelowego modelu zamku w Prusach (Wasik 2016, s. 317-319). Przekształcenia w nowym duchu starych założeń nieregularnych sprawiły, że ich pierwotne formy zostały „wchłonięte” przez wielkie założenia 

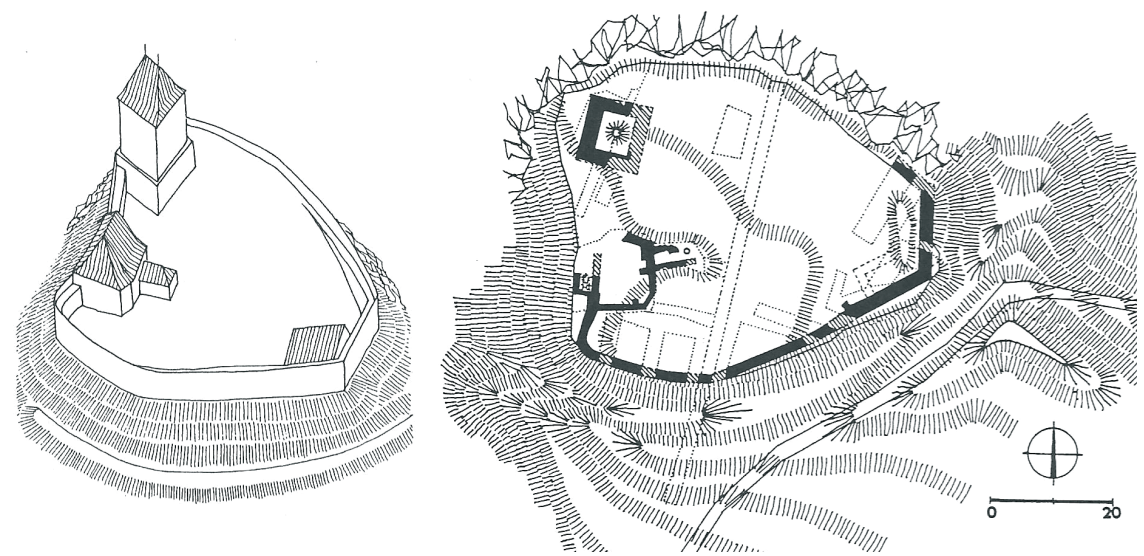

Ryc. 18. Bradlo, Czechy. Rzut i rekonstrukcja zamku krzyżackiego z końca XIII lub przełomu XIII i XIV wieku (wg Durdík 2000)

Fig. 18. Bradlo, Bohemia. Plan and reconstruction of the Teutonic Order's castle from the end of the $13^{\text {th }}$ century or the turn of the $13^{\text {th }}$ and the $14^{\text {th }}$ centuries (after Durdík 2000)

zamkowe i stały się do niedawna niedostrzegalne. Jednak mimo postępu stanu wiedzy, stan badań archeologiczno-architektonicznych nad tymi obiektami jest nadal niewystarczający i wymaga poszerzenia.

\section{Bibliografia}

Źródła

CDW - Codex Diplomaticus Warmiensis oder Regesten und Urkunden zur Geschichte Ermlands, wyd. C. P. von Woelky, J. M. Saage, t. 1, Braunsberg 1860.

Dusburg - Piotr z Dusburga. Kronika ziemi pruskiej, tłum. S. Wyszomirski, wstęp i komentarze J. Wenta, Toruń 2004.

Wykaz skrótów

Wczesnośredniowieczne grodziska - Wczesnośredniowieczne grodziska ziemi chetmińskiej. Katalog źródel, red. J. Chudziakowa, Toruń

Adamczyk J. L.

2004 Fortyfikacje state na polskim przedmurzu od połowy XV do końca XVII wieku, Kielce. 
Arszyński M.

1995 Budownictwo warowne zakonu krzyżackiego w Prusach (1230-1454), Toruń.

2000 Zamki i umocnienia krzyżackie, [w:] Państwo zakonu krzyżackiego w Prusach. Podziały administracyjne i kościelne od XIII do XVI wieku, red. Z. H. Nowak, Toruń, s. 29-43.

2010 Architektura warowna zakonu krzyżackiego w Prusach, [w:] Fundacje artystyczne na terenie państwa krzyżackiego w Prusach, t. 2: Eseje, red. B. Pospieszna, Malbork, s. 7-45.

Boguszewicz A.

1998 Przemiany w XIII-wiecznym śląskim budownictwie obronnym, [w:] Kultura średniowiecznego Śląska i Czech. , Rewolucja” XIII wieku, red. K. Wachowski, Wrocław, s. 97-111.

Boguwolski R.

1975 Pokrzywno Zamek, pow. Grudziadz, Stanowisko 1, Informator Archeologiczny. Badania rok 1974, Warszawa, s. 191-192.

1994 Wieldzadz, [w:] Wczesnośredniowieczne grodziska, s. 190-194.

Boguwolski R., Grupa M.

1994 Pokrzywno, [w:] Wczesnośredniowieczne grodziska, s. 140-144.

Boguwolski R., Kola A.

1994 Stup, [w:] Wczesnośredniowieczne grodziska, s. 160-165.

Boguwolski R., Kurzyńska M.

2001 Archeologia pólnocnej części ziemi chetmińskiej, Grudziądz.

Byczko T.

1962 Z badań nad geneza rozplanowania zamku krzyżackiego, Rocznik Olsztyński, nr 4, s. 135-165.

Chęć A.

2009 Sprawozdanie z badań archeologiczno-architektonicznych na terenie zamku krzyżackiego w Toruniu (st. 1), maszynopis w archiwum Wojewódzkiego Urzędu Ochrony Zabytków w Toruniu, Toruń.

Chorowska M.

2003 Rezydencje średniowieczne na Ślasku. Zamki, pałace, wieże mieszkalne, Wrocław.

Chudziak W., Kurzyńska M.

2012 Wczesne średniowiecze, [w:] Zamek w Grudziadzu w świetle badań archeologiczno-architektonicznych. Studia i materiaty, red. M. Wiewióra, Toruń, s. $173-189$.

Chudziakowa J., Kola A.

1974 Źródta archeologiczne z terenu zamku krzyżackiego w Toruniu, WarszawaPoznań.

Clasen K. H.

1927 Die mittelalterliche Kunst im Gebiete des Deutschordensstaates Preussen,

t. 1: Die Burgbauten, Königsberg. 
Czaja R.

2013 Miasta i przestrzeń miejska w państwie zakonu krzyżackiego w Prusach, [w:] Zakon krzyżacki w Prusach i Inflantach. Podziały administracyjne i kościelne w XIII i XVI wieku, red. R. Czaja, A. Radzimiński, Toruń, s. 81-106.

Durdík T.

1994 Erforschung der Mittelalterlichen Burgen in West- und Südböhmen, Castellologica Bohemica, nr 4, s. 7-26.

$2000 \quad$ Ilustrovaná encyklopedie českých hradů, Praha.

2004 Die Kommenden und Burgen der Ritterorden in Böhmen, [w:] Castrum Bene, nr 5: Castle and church, red. L. Kajzer, H. Paner, Gdańsk, s. 39-59.

Durdík T., Bolina P.

2001 Středověkẻ hrady v Čechách a na Moravě, Praha.

Dygo M.

2008 Początki i budowa władztwa zakonu krzyżackiego (1226-1309), [w:] Państwo zakonu krzyżackiego w Prusach. Władza i społeczeństwo, red. E. Kubicka, K. Kwiatkowski, Warszawa, s. 53-78.

Frycz J.

1963 Zamek krzyżacki w Toruniu, Rocznik Muzeum w Toruniu, t. 1, z. 3, s. 79-94. Guerquin B.

1984 Zamki w Polsce, Warszawa.

Herrmann Ch.

2007 Mittelalterliche Architektur im Preussenland. Untersuchungen zur Frage der Kunstlandschaft und-Geographie, Petersberg-Olsztyn.

Heym W.

1933 Das ,Altschlößchen” in Marienwerder, Zeitschrift des historischen Vereins für Regierungsbezirk Marienwerder, t. 69, s. 3-28.

Jacobi H.

1996 Die Ausgrabungsergebnisse der Deutschordensburgen Graudenz und Roggenhausen. Ein Beitrag zur baugeschichtlichen Entwicklung der Ordensburgen, oprac. U. von Arnold, Braubach.

Jóźwiak S.

1997 Powstanie i rozwój struktury administracyjno-terytorialnej zakonu krzyżackiego na Kujawach i ziemi chetmińskiej w latach 1246-1343, Toruń.

2001 Centralne i terytorialne organy władzy zakonu krzyżackiego $w$ Prusach w latach 1228-1410, Toruń.

2015 Krzyżacki murowany zamek $w$ Kłajpedzie $w$ świetle średniowiecznych źródet pisanych, Klio, t. 32/1, s. 3-29.

Jóźwiak S., Trupinda J.

2012a Krzyżackie zamki komturskie w Prusach. Topografia i układ przestrzenny na podstawie średniowiecznych źródet pisanych, Toruń.

2012b Krzyżacki zamek komturski w Grudziądzu w średniowieczu na podstawie źródet pisanych. Chronologia powstania i układ przestrzenny, [w:] Zamek w Grudziądzu w świetle badań archeologiczno-architektonicznych. Studia i materiaty, red. M. Wiewióra, Toruń, s. 49-57. 
Kajzer L.

1993 Zamki i społeczeństwo. Przemiany architektury i budownictwa obronnego w Polsce $w$ X-XVIII wieku, Łódź.

Kajzer L., Kołodziejski S., Salm J.

2001 Leksykon zamków w Polsce, Warszawa.

Kola A.

1991 Grody ziemi chetmińskiej w późnym średniowieczu, Torun.

1994 Kałdus, [w:] Wczesnośredniowieczne grodziska, s. 85-93.

Kutzner M.

1995 Propaganda władzy w sztuce Zakonu Niemieckiego w Prusach, [w:] Studia Borussico-Baltica Toruniensia Historiae Artium, t. 2: Sztuka w kręgu Zakonu Krzyżackiego w Prusach i Inflantach, red. M. Woźniak, Toruń, s. 17-66.

Liessem U.

1996 Die Bauten des Deutschen Ordens in Koblenz bis zum Ende des 13. Jahrhunderts, [w:] Forschungen zu Burgen und Schlössern, t. 2: Burgenbau im späten Mittelalter, red. H. Hofrichter, G. U. Großmann, München-Berlin, s. 49-59.

2004 Elemente des Burgenbaus bei einigen Niderlassungen des Deutschen Ordens, [w:] Castrum Bene, nr 5: Castle and church, red. L. Kajzer, H. Paner, Gdańsk, Marciniak-Kajzer A. s. $103-117$.

2002 Drewno na zamkach, czyli o czym na ogót zapominamy, [w:] Zamki i przestrzeń społeczna w Europie Środkowej $i$ Wschodniej, red. M. Antoniewicz, Warszawa, s. 491-496.

Matuszewska-Kola W.

1978 Wyniki prac wykopaliskowych prowadzonych na grodzisku w Wieldzadzu, pow. Wabrzeźno, w 1971 r., [w:] Komunikaty Archeologiczne. Badania wykopaliskowe na terenie województwa bydgoskiego w latach 1970-1972, Bydgoszcz, s. 225-229.

Nawrocki Z.

2005 Zamek krzyżacki w Toruniu. Dzieje budowy, upadek, ponowne zagospodarowanie, Rocznik Muzeum w Toruniu, t. 13/14, s. 7-72.

Ose I.

2004 Neue Erkentnisse über die Ordensburgen in Lettland, [w:] Castrum Bene, nr 5: Castle and church, red. L. Kajzer, H. Paner, Gdańsk, s. 119-135.

Pawłowski H., Wierzbicki R., Markowska A.

1984 Inwentaryzacja budowlano-konserwatorska - aktualizacja. Zamek Wysoki. Bierzgłowo, maszynopis w archiwum Wojewódzkiego Urzędu Ochrony Zabytków w Toruniu, sygn. W/1002, Toruń.

Poliński D.

2003 Późnośredniowieczne osadnictwo wiejskie $w$ ziemi chetmińskiej, Toruń.

2005 Gród czy zamek? Z badań nad najwcześniejszymi krzyżackimi obiektami obronnymi w ziemi chetmińskiej, Archaeologia Historica Polona, t. 15/1, s. $181-196$. 
2007a „Chetmińskie” warownie zakonu na pograniczu krzyżacko-pruskim i krzyżacko-polskim, [w:] Pogranicze polsko-pruskie i krzyżackie, t. 2, red. K. Grążawski, Włocławek-Brodnica, s. 155-177.

$2007 b \quad W c z e s n e$ warownie krzyżackie w Prusach $w$ kontekście miejscowych obiektów obronnych o umocnieniach drewniano-ziemnych, Archaeologia Historica Polona, t. 16, s. 41-61.

Powierski J.

1983 Struktura osadniczo-terytorialna ziemi chetmińskiej i Pomezanii a ksztattowanie się administracji grodowej (do 1283 r.), [w:] Średniowieczne zamki Polski północnej. Wybór materiałów z sesji, red. A. Pawłowski, Malbork, s. 15-32.

Rajski P.

2013 Fortifications made of wood and earth in late medieval castles of the Sudety mountains, [w:] Weapons bring peace? Warfare in Medieval and Early Modern Europe, Wratislavia Antiqua 18, red. L. Marek, Wrocław, s. 239-253.

Rzeczkowska-Sławińska M.

1983 Zamek w Pokrzywnie, Rocznik Grudziądzki, t. 8, s. 5-31.

Sławińska M.

1969 Zamek w Pokrzywnie, Biuletyn Historii Sztuki, R. 31, s. 238-242.

Steinbrecht C.

1888 Die Baukunst des Deutschen Ritterordens in Preussen, t. 2: Preussen zur Zeit der Landmeister, Berlin.

Torbus T.

1998 Die Konventsburgen in Deutschordensland Preussen, München.

Toeppen M.

1880 Zur Baugeschichte der Ordens- und Bischofsschlösser in Preußen, Zeitschrift des Westpreußischen Geschichtsvereins, nr 1, s. 1-44.

Wasik B.

2014 Prace budowlane na zamkach w Grudziądzu i Toruniu u progu XIV wieku. Przyczynek do badań nad średniowiecznymi warsztatami budowlanymi w Prusach, Rocznik Grudziądzki, t. 22, s. 99-112.

2015 Zamek $w$ Radzyniu Chetmińskim. Technika i etapy budowy, Ochrona Zabytków, t. 68, nr 1, s. 167-181.

2016 Budownictwo zamkowe na ziemi chetmińskiej (od XIII do XIV wieku), Toruń. Wiewióra M.

2012 Stratygrafia kulturowa Góry Zamkowej. Synchronizacja warstw i analiza obiektów kulturowych, [w:] Zamek w Grudziadzu ws świetle badań archeologiczno-architektonicznych. Studia i materiały, red. M. Wiewióra, Toruń, s. 74-125.

Zimnowodna-Krajewska B.

2012 Analiza źródeł architektonicznych, [w:] Zamekw Grudziądzu w świetle badań archeologiczno-architektonicznych. Studia i materiały, red. M. Wiewióra, Toruń, s. 127-158. 


\section{THE ORIGINS OF THE TEUTONIC ORDER'S CASTLES IN CHEŁMNO LAND. FIRST STRONGHOLDS AND MORTARED STRUCTURES}

Summary

The Teutonic Knights after their arrival to Kuyavian side of the Vistula River durin following decades of the $13^{\text {th }}$ century erected a series of wooden and earthen forts, which role was to secure conquered lands and to establish the new order. The $13^{\text {th }}$ century was a crucial period in Central Europe. There occurred major social and economic changes, linked to the introduction of new feudal system, the development of new settlement and legal system. In Bohemia, as well as in Silesia, there were characteristic castles of transition type associated with the central authority - centres of new administration and settlement. They did not constitute a simple continuation of early medieval strongholds, but, in fact, they were constructed with impermament materials, usually erected on a 'greenfield'. Fortification constituted a perimeter of ramparts without internal wooden structures, strengthened from the outside by a wooden or stone wall. Building were erected in timberframed construction, or other impermament one and they were coupled with ramparts.

Due to the limited state of research the reconstruction of the characteristics of wooden and earthen strongholds of the Teutonic Order from this period is not easy. In contrast to Bohemia, in Chełmno Land more often in the $13^{\text {th }}$ century they were built in places of early medieval strongholds, which should be explained by wartime urgency and convenient location. Fortifications constituted ramparts, and buildings erected in impermament constructions were coupled with them. Strongholds formed in this way were associated with the needs of new monastic rulers of these lands, and therefore they included chapels required by the rule of the Teutonic Order, and perhaps also refectories. The socio-economic background, as well as the general features of the Teutonic Order's wooden and earthen strongholds lead to the conclusion that they should be classified as so-called castles of transition type.

From the mid- $13^{\text {th }}$ century (Torun), and above all from the 1270 s (Bierzgłowo, Grudziądz, Pokrzywno) selected strongholds, located in the centres of the newly formed commandries of Chełmno Land, were transformed from wooden and earthen into mortared ones. As first were erected single mortared buildings, and it was characteristic that the original mortared building was located in place of future chapel. Instead the construction of castle wings was not planned back then, they were created later, from the end of the $13^{\text {th }}$ century, according to completely new concepts. In their original form these complexes probably were never completed. Simultaneously with these works construction of outer walls proceeded, replacing old wooden and earthen fortifications, starting from the most vulnerable side. Therefore, they were irregular complexes with single mortared and probably wooden buildings originating from the previous period. In this respect they resembled seats of the Teutonic Order commandries from Germany and Bohemia. Of particular interest is the analogy to the Teutonic Order castle Bradlo in Bohemia, where a similar spatial concept is perceptible.

Recent research has produced a lot of new information about the origins of the Teutonic Order's castles, but it is still insufficient knowledge, requiring enlargement. 